\title{
Comparative assessment and safety issues in state-of-the- art hydrogen production technologies
}

\author{
Giulio Guandalini", Stefano Campanari, Gianluca Valenti
}

Politecnico di Milano, Department of Energy, Via Lambruschini 4, 20156 Milano, Italy

ABSTRACT

This work discusses the development of a benchmark comparison among hydrogen pro-duction technologies, focussing on the assessment of their operating conditions by the point of view of the potential impact on safety. The analysis focuses on state-of-the-art, fully industrialized and commercial technologies, or at least with established early-market availability, not considering unconventional or emerging technologies still featuring a low technology readiness level. After a selection of hydrogen production technologies and their classification according to the possible feedstock, hydrogen purity and plant size, operating conditions and relative component sizes were calculated. Temperatures, pressures and chemical features are given in the most important points, as well as relative size of components, considering that these factors can be important by the point of view of safety. The qualitative comparison of the investigated technologies evidenced the presence of flammable and toxic mixtures at high temperature common to all the natural gas fed technologies, while gasifiers generally operates at lower temperature. ATR and gasifiers exhibit flammable and toxic gases at high pressure, as well as highly reactive streams (i.e. pure oxygen). This last is an aspect common also to electrolysis and POX. Common ranges for operating conditions are provided as a support for subsequent safety evaluation on how critical is a certain plant by the point of view of safety.

\footnotetext{
* Corresponding author.

E-mail address: giulio.guandalini@polimi.it (G. Guandalini).
} 


\section{Introduction}

Hydrogen has been studied for decades as a clean energy carrier, starting after the oil crisis in the 70's, with the potential of replacing in the long-term the conventional hydrocarbons obtained from fossil resources both for stationary applications (e.g. power generation or distributed combined heat and power) and for the mobility (e.g. from road transportation to aeronautical applications) [1-3]. Research activities carried out in most industrialized countries have led to the development of novel technologies for the production, storage, distribution and use of hydrogen [4-7], with a number of demonstration projects taking place to foster hydrogen applications and international studies aiming to develop a technology deployment roadmap [8]. Within such framework, it is also recognized that a fundamental part of the possible success trajectory of a 'hydrogen economy' lies into the public awareness of hydrogen technologies and its safety issues [9].

This work is dedicated to a comparative assessment of hydrogen production technologies, focussing on the analysis of their operating conditions by the point of view of the potential impact on safety, according to an approach developed within the European FP7 funded project H2TRUST [10]. The scope is to compare industrialized and commercial technologies, or at least with an established early-market availability, having the most important impact on public awareness and trust in hydrogen technologies and applications. Due to that, this work does not consider all possible options for hydrogen production, distribution and storage and it excludes from a systematic analysis all options still featuring a low technology readiness level as well as unconventional or emerging technologies. Nevertheless, some of them are sometimes cited in the work for clarity of explanation and comparison.

For each type of plant, a corresponding plant layout is developed with a common framework, evaluating with a specific table the related stream operating conditions (pressure, temperatures, mass flow rates, chemical composition and presence of flammable components). An additional analysis compares the most important plant components by the point of view of relative size, evaluated on a qualitative basis aiming to evidence the presence of bulky equipment, especially when processing hazardous streams.

This work can effectively support a subsequent safety evaluation, since an analysis of the recurrence of streams featuring high pressure/high temperature/high content of combustible, chemically reactive or toxic species, as well as the presence of large size reactors with hazardous contents, could address in evaluating how critical is a certain plant by the point of view of safety.

\section{Methodology}

The analysis is based primarily on data collected from open literature on hydrogen production [11-14]; other references are included in the text), as well as from specific information provided by industrial partners within the project H2TRUST [10]. Aiming to setup a complete set of results, data are integrated with numerical simulations of specific plant configurations carried out using the process simulation software Aspen Plus ${ }^{\circledR}$ [15]. In the following tables, calculation assumptions are evidenced in bold, while other quantities are results of Aspen Plus ${ }^{\circledR}$ simulations; thermochemical properties and chemical equilibrium are calculated by the software according to SRK equation of state and internal database of parameters. Reactors operating temperatures are usually specified from literature, in order to satisfy restrictions on catalyst operative ranges. Specific additional assumptions are reported for each case study.

The routes for hydrogen production have been identified using a straightforward discrimination based on the possible feedstock: hydrocarbons, solid fuels or electricity. More precisely, the considered feedstocks for $\mathrm{H}_{2}$ production are the following:

- Natural gas and hydrocarbons (including LPG, ethanol, biogas), using reforming-based processes (either using steam reforming, autothermal reforming or through partial oxidation).

- Solid or heavy fuels (including coal, biomass, refinery residues) through gasification/pyrolysis processes.

- Electricity through electrolysis.

The most common production routes are by far in the first and third category, namely natural gas steam reforming or electrolysis. Use of solid and heavy fuels specifically for hydrogen production is presently limited to rather few demonstration plants, whereas solid fuels and biomass are converted into syngas through gasification or pyrolysis and for the majority directly used without hydrogen purification or separation. The work will deal with the case of gasification of heavy residues, taken as a representative case, typically carried out in refineries where at least part of the syngas is purified to hydrogen for internal uses. 
A further step into detailed discrimination of the technologies applied in hydrogen production takes into consideration other factors as production scale and grade of hydrogen purity required, when these factors influence significantly the plant configuration with inclusion of new components which can be important by the point of view of safety.

Fig. 1 presents a schematic view of the different technologies applied to the conversion of raw material to hydrogen. This conceptual summary is taken as a starting point for the definition of plant designs addressed in this work.

As anticipated in the introduction, this work analyses mature technologies used for production of hydrogen, focussing mostly on the processes which are most used as for today. Therefore the description in Fig. 1 is not including technologies in early stage of development, R\&D or niche applications, that are beyond the scope of the work. A comprehensive list could include other processing techniques, for instance solar driven thermochemical water splitting, microbial and green algae production, hydrocarbon decomposition (e.g. dry reforming), steam-iron process, plasma reforming, adsorption enhanced reforming, photocatalytic/photobiologic processes, dark fermentation, SOEC electrolysis etc. [8]. A brief summary of these technologies is presented in Table 1.

A large effort is currently spent worldwide in hydrogen technologies, mainly as research and development with more than one billion dollars public investment in R\&D annually [17]. Nevertheless, the market is already developed in many industrial sectors (i.e. chemicals and refinery). According to 'Hydrogen Generator Market - Global Industry Analysis, 2016-2024' report [18], the global hydrogen generator market revenue stood at US\$792.44 million in 2015 and is expected to reach US $\$ 1255.76$ million by 2024 . Onsite generation product type held the largest share (72.86\%) in 2015. By process type, steam reformer held the largest share, i.e. $89.53 \%$ and $89.24 \%$ for onsite and portable hydrogen generators, respectively, in 2015. By application, chemical processing held the largest market share $(57.81 \%)$ in 2015 . By capacity, $3 \mathrm{~kW}$ and above held the largest market share (38.69\%) in 2015.

Table 2 lists a summary of the relevant plant designs covered by this work. In addition to the plant size, the table addresses a classification according to the following criteria:

\section{- Desulphurization}

Desulphurization is applied to fuel and syngas feedstock ahead of catalytic reactors involved in the hydrogen production process. It can be divided in two categories, based on operating temperature. This implies a different arrangement in the plant configuration and different streams conditions.

\section{- Purity and purification}

Highest purity is generally obtained by electrolysis plants or through PSA purification applied to syngas generated by SR plants. The size of the PSA section depends on the quantity of contaminants to be removed from the syngas (e.g. $\mathrm{CO}, \mathrm{CO}_{2}$, $\mathrm{N}_{2}$ ); ATR and POX plants using air as oxidant have a higher concentration of $\mathrm{N}_{2}$ and are generally not suitable for highest purity grades. Other purification routes include preferential oxidation, usually applied to smaller SR plants for CO removal, without influence on non-combustible contaminants. The grade of purity of the final product is defined with a standard decimal notation (e.g. High purity grade 4.0 for $99.99 \% \mathrm{H}_{2}$; Ultra High purity grade 5.5 for $99.9995 \% \mathrm{H}_{2}$ and so on).

In all cases resulting from Fig. 1 (labelled C1 to C8) it is defined a conceptual plant scheme, as well as the corresponding reference operating conditions (e.g. streams pressure, temperature, chemical features in the most important points).

Quantities are indicated with a range according to most common literature evidences, with mass flow rates normalized towards a production of $1 \mathrm{Nm}^{3} / \mathrm{h}$ of hydrogen. Stream specification may be completed with a note specifying the
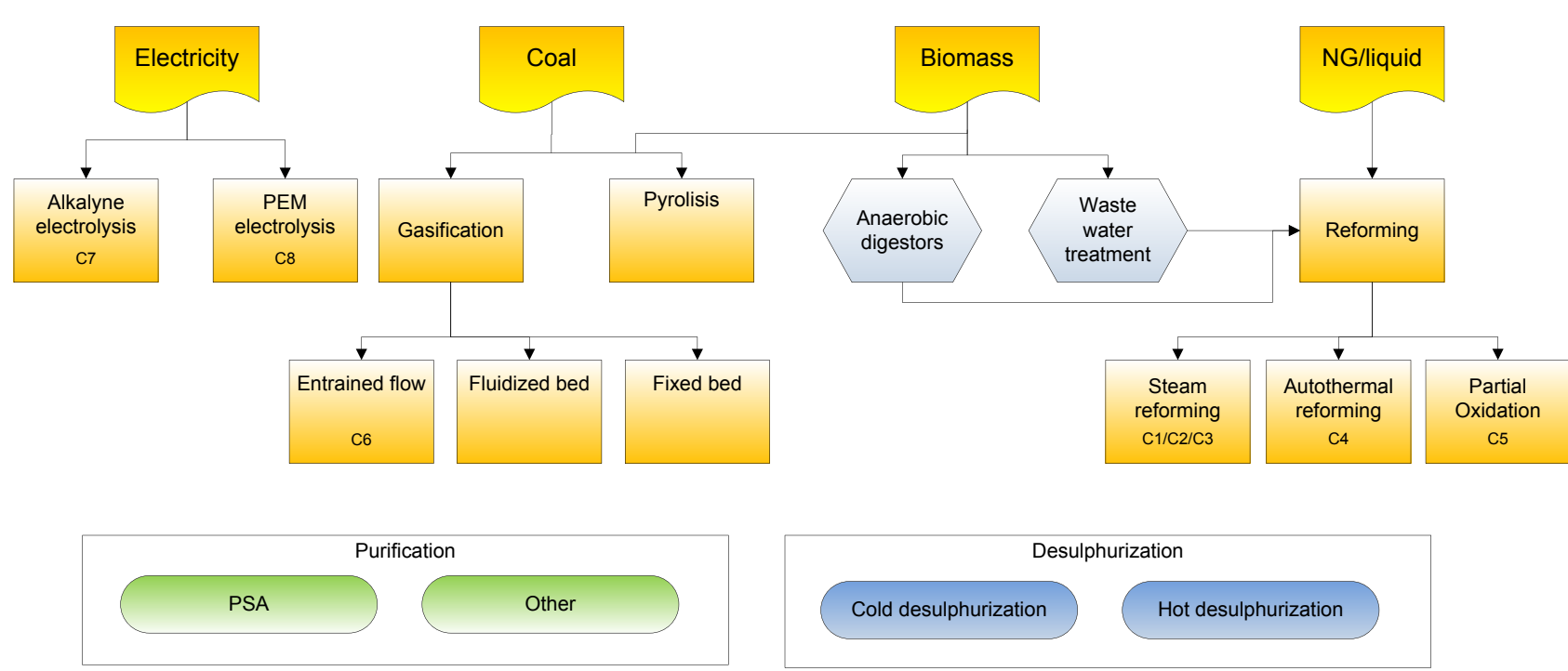

Fig. 1 - Hydrogen production techniques considered in reference benchmark analysis, and related plant configurations (C1-C8). 
Table 1 - Summary of innovative (not yet industrialized) hydrogen production technologies [16].

\begin{tabular}{|c|c|c|c|}
\hline Technology & Feed and energy input & Advantages & Drawbacks \\
\hline SOEC electrolysis & $\begin{array}{l}\text { Water } \\
\text { Electricity and heat (nuclear } \\
\text { power, concentrated solar } \\
\text { radiation) }\end{array}$ & $\begin{array}{l}\text { High efficiency } \\
\text { Replace part of electricity } \\
\text { requirement with thermal energy } \\
\text { Solid electrolyte (not caustic, no } \\
\text { circulation issues) }\end{array}$ & $\begin{array}{l}\text { High temperature heat required } \\
\left(>700^{\circ} \mathrm{C}\right) \\
\text { High cost of materials } \\
\text { Lifetime }\end{array}$ \\
\hline $\begin{array}{l}\text { Thermochemical water } \\
\text { splitting }\end{array}$ & $\begin{array}{l}\text { Water } \\
\text { Concentrated solar } \\
\text { radiation }\end{array}$ & $\begin{array}{l}\text { Only heat and water as input } \\
\text { No by-products (only hydrogen and } \\
\text { oxygen) } \\
\text { Several possible intermediate steps } \\
\text { and chemical enhancer } \\
\text { documented in literature }\end{array}$ & $\begin{array}{l}\text { Extremely high temperature } \\
\text { required }\left(>2000{ }^{\circ} \mathrm{C}\right) \text { or high } \\
\text { pressures in presence of chemical } \\
\text { reagents } \\
\text { Large inventories of highly } \\
\text { hazardous corrosive materials }\end{array}$ \\
\hline $\begin{array}{l}\text { Microbial production (Green } \\
\text { algae, cyanobacteria) }\end{array}$ & Solar radiation & $\begin{array}{l}\text { Primary fed is only water } \\
\text { No particular materials or } \\
\text { chemicals required }\end{array}$ & $\begin{array}{l}\text { Strict control on environmental } \\
\text { conditions } \\
\text { Large requirement of surface area } \\
\text { to capture the sufficient amount of } \\
\text { light } \\
\text { Microorganisms sensible to oxygen } \\
\text { accumulation } \\
\text { Mixed } \mathrm{H}_{2} \text { and } \mathrm{O}_{2} \text { production with } \\
\text { safety issues }\end{array}$ \\
\hline Dry reforming & $\begin{array}{l}\text { Natural gas } \\
\text { Syngas } \\
\text { Raw biogas }\end{array}$ & $\begin{array}{l}\text { Lower } \mathrm{H}_{2} / \mathrm{CO} \text { ratio suitable for } \\
\text { synthesis of fuels or chemicals } \\
\text { Conversion of low quality gases } \\
\text { (with carbon dioxide) } \\
\text { GHG gases as reactants }\end{array}$ & $\begin{array}{l}\text { Higher tendency to carbon } \\
\text { deposition } \\
\text { High water production and lower } \\
\text { yields } \\
\text { Higher temperatures with respect } \\
\text { to traditional SMR }\end{array}$ \\
\hline Plasma reforming & $\begin{array}{l}\text { Hydrocarbons } \\
\text { Electricity or heat }\end{array}$ & $\begin{array}{l}\text { Overall reactions are the same of } \\
\text { traditional reforming, but no } \\
\text { catalyst } \\
\text { Possibility of feeding heavy } \\
\text { hydrocarbons }\end{array}$ & $\begin{array}{l}\text { Very high energy consumption for } \\
\text { plasma generation by electricity or } \\
\text { heat } \\
\text { High electrode erosion }\end{array}$ \\
\hline $\begin{array}{l}\text { Membrane reactors or } \\
\text { adsorption enhanced } \\
\text { reforming }\end{array}$ & Hydrocarbons & $\begin{array}{l}\text { Improved conversion and } \\
\text { selectivity due to product removal } \\
\text { Lower temperatures }\end{array}$ & $\begin{array}{l}\text { Thermal and mechanical stability } \\
\text { of materials } \\
\text { Selectivity } \\
\text { High costs of materials or high } \\
\text { regeneration cost }\end{array}$ \\
\hline Dark fermentation & Biomass & $\begin{array}{l}\text { Several anaerobic bacteria and } \\
\text { algae available } \\
\text { Very simple reactor structure }\end{array}$ & $\begin{array}{l}\text { Stable operation conditions } \\
\text { required } \\
\text { Large amount of substrate } \\
\text { required, rich in carbohydrates } \\
\text { Syngas production (purification is } \\
\text { required) } \\
\text { Production of intermediate acids } \\
\text { which reduce selectivity to } \\
\text { hydrogen }\end{array}$ \\
\hline Photofermentation & $\begin{array}{l}\text { Biomass } \\
\text { Solar radiation }\end{array}$ & $\begin{array}{l}\text { Direct biological production of } \\
\text { hydrogen } \\
\text { Bacteria can be used in a wide } \\
\text { range of conditions } \\
\text { No particular materials or } \\
\text { chemicals required }\end{array}$ & $\begin{array}{l}\text { Stable operating conditions } \\
\text { required } \\
\text { High energy requirement } \\
\text { Slow process } \\
\text { Hydrogen re-oxidation has to be } \\
\text { inhibited }\end{array}$ \\
\hline Photoelectrolysis & $\begin{array}{l}\text { Water } \\
\text { Solar radiation }\end{array}$ & $\begin{array}{l}\text { Direct decomposition of water in } \\
\text { an electrochemical cell by means } \\
\text { of direct sun radiation }\end{array}$ & $\begin{array}{l}\text { Very low efficiency } \\
\text { Strict requirement on materials } \\
\text { properties for coupling with solar } \\
\text { spectrum } \\
\text { Issues of material's resistance to } \\
\text { corrosion and crystalline structure } \\
\text { quality }\end{array}$ \\
\hline
\end{tabular}

possible hazards (e.g. a fluid may be flammable, toxic, acid or caustic etc.).

Another key issue in a safety analysis is the physical quantity of hazardous substances which are present in a plant; as a first approximation, this quantity is proportional to the size of the plant equipment (e.g. reactors, vessels, storages). A quantitative definition of component size is not possible since it depends on a number of plant-specific 
Table 2 - List of hydrogen production plants discriminated by design criteria.

\begin{tabular}{|c|c|c|c|c|c|c|c|c|}
\hline \multirow{2}{*}{$\begin{array}{l}\text { Feedstock } \\
\text { Technology } \\
\text { Criteria/Plant }\end{array}$} & \multicolumn{5}{|c|}{ Gas/liq. hydrocarbon fuel } & \multirow{2}{*}{$\begin{array}{c}\text { Solid fuel } \\
\text { Gasification } \\
\text { (Entrained } \\
\text { flow) }\end{array}$} & \multicolumn{2}{|c|}{ Electricity } \\
\hline & $\begin{array}{l}\text { Steam } \\
\text { reforming } \\
\text { (large scale) }\end{array}$ & $\begin{array}{r}\mathrm{r} \epsilon \\
\text { (sme }\end{array}$ & ing & $\begin{array}{l}\text { Auto } \\
\text { thermal } \\
\text { reforming }\end{array}$ & $\begin{array}{c}\text { Partial } \\
\text { oxidation }\end{array}$ & & $\begin{array}{c}\text { Alkaline } \\
\text { electrolysis }\end{array}$ & $\begin{array}{c}\text { PEM } \\
\text { electrolysis }\end{array}$ \\
\hline NG/liquid hydrocarbons & $\mathrm{X}$ & $\mathrm{X}$ & $\mathrm{X}$ & $\mathrm{X}$ & $\mathrm{X}$ & & & \\
\hline Biogas & & $\mathrm{X}$ & $\mathrm{X}$ & & & & & \\
\hline Coal/heavy residues & & & & & & $\mathrm{X}$ & & \\
\hline Electricity & & & & & & & $x$ & $X$ \\
\hline \multicolumn{9}{|l|}{ Plant size } \\
\hline Small - medium & & $\mathrm{X}$ & $\mathrm{X}$ & & & & $\mathrm{X}$ & $\mathrm{X}$ \\
\hline Large & $\mathrm{X}$ & & & $\mathrm{X}$ & $\mathrm{X}$ & $\mathrm{X}$ & $\mathrm{X}$ & \\
\hline \multicolumn{9}{|l|}{ Desulfurization } \\
\hline Hot & $\mathrm{x}$ & & & $\mathrm{X}$ & & $\mathrm{X}$ & n.a. & \\
\hline Cold & & $\mathrm{X}$ & $\mathrm{x}$ & & & & & \\
\hline \multicolumn{9}{|l|}{ Purity } \\
\hline Grade $4.0-6.0$ & $\mathrm{X}$ & & $\mathrm{X}$ & & & $\mathrm{X}$ & $\mathrm{X}$ & $\mathrm{X}$ \\
\hline Grade $2.0 \div 4.0$ & & & $\mathrm{X}$ & $\mathrm{X}$ & $\mathrm{X}$ & $\mathrm{X}$ & & \\
\hline$<99 \%$ & & $\mathrm{X}$ & & & & & & \\
\hline \multicolumn{9}{|l|}{ Purification } \\
\hline PSA & $\mathrm{X}$ & & $\mathrm{X}$ & $\mathrm{x}$ & $\mathrm{X}$ & $\mathrm{x}$ & & \\
\hline Other & & $\mathrm{X}$ & & & & & $\mathrm{x}$ & $\mathrm{x}$ \\
\hline Configuration & C1 & $\mathrm{C} 2$ & C3 & $\mathrm{C} 4$ & $\mathrm{C} 5$ & C6 & C7 & $\mathrm{C} 8$ \\
\hline
\end{tabular}

features, ranging from the exact plant capacity to design specification of all its components. However, it is possible to give a qualitative indication of the presence of specially large reactors or pieces of equipment. Therefore another table evidences in a qualitative way the relative size of the most important plant components, classified as small $(+)$, medium $(++)$ or large $(+++)$ aiming to evidence the presence of bulky equipment, especially when processing hazardous streams.

\section{Production from natural gas, biogas and liquid fuels}

Hydrogen production from gaseous and liquid fuels (natural gas, biogas, light hydrocarbons) is mainly based on two reactions. The first is steam reforming, namely (focussing on methane):

$\mathrm{CH}_{4}+\mathrm{H}_{2} \mathrm{O} \rightarrow \mathrm{CO}+3 \mathrm{H}_{2} \quad \Delta \mathrm{H}_{298 \mathrm{~K}}^{\circ}=206 \mathrm{~kJ} / \mathrm{mol}$

that produces a mixture of carbon monoxide (CO) and hydrogen $\left(\mathrm{H}_{2}\right)$. To improve the conversion to hydrogen, usually a successive water gas shift (WGS) reaction is included in the process:

$\mathrm{CO}+\mathrm{H}_{2} \mathrm{O} \rightarrow \mathrm{CO}_{2}+\mathrm{H}_{2} \quad \Delta \mathrm{H}_{298 \mathrm{~K}}^{\circ}=-41 \mathrm{~kJ} / \mathrm{mol}$

Both reactions are carried out with proper catalysts to enhance the hydrogen production rate. Due to the strong endothermic nature of the steam reforming reaction, an external heat source is required, typically obtained burning a fraction of the feeding in the reactor. In some technologies, a partial oxidation of methane in oxygen or air substoichiometric atmosphere is used to produce hydrogen and carbon monoxide:
$\mathrm{CH}_{4}+\frac{1}{2} \mathrm{O}_{2} \rightarrow \mathrm{CO}+2 \mathrm{H}_{2} \quad \Delta \mathrm{H}_{298 \mathrm{~K}}^{\circ}=-38 \mathrm{~kJ} / \mathrm{mol}$

that also has to be promoted by a catalyst; the mixture is later sent to further conversion (e.g. through WGS) and purification sections to produce pure hydrogen.

In case of presence of higher $\left(\mathrm{C}_{2+}\right)$ hydrocarbons, a preliminary step of prereforming is generally included, in order to crack longer hydrocarbon chains. The product stream is a syngas mixture of different species, whose composition strongly depends on the technology and the feeding; an hydrogen separation section, placed downstream the syngas production, is therefore mandatory.

The process of steam reforming for hydrogen production is used also with light hydrocarbons other than natural gas, such as naphtha, LPG, ethanol or diesel, though in much lesser cases. Such applications are mainly of specific interest with on-board reforming for mobile/portable applications. In general the reforming process of these hydrocarbons are quite similar to that of NG reforming; the main differences may fall on a more complex desulphurization system and the use of higher steam to carbon ratio to reduce coking.

Alternatively, a feasible way to reduce the impact of hydrogen production would be the use of biogas as feedstock. Typical technologies for biogas production can be anaerobic digesters of agricultural residues, landfill gas or waste water (sewage) treatment. This processes lead to a mixture of the same components of natural gas, but in a very different ratio, as exemplified in Table 3.

The gas mixture could be then processed by a steam reforming plant. As evident, the methane content in biogas is much lower than in natural gas. Moreover, the higher sulphur content forces the implementation of larger purification systems, while the large amount of $\mathrm{CO}_{2}$ has a negative influence 
Table 3 - Comparison among different biogas and natural gas common compositions [5].

\begin{tabular}{lllcccc}
\hline Specie & $\begin{array}{c}\text { Landfill } \\
\text { biogas }\end{array}$ & $\begin{array}{c}\text { Anaerobic } \\
\text { digestor } \\
\text { biogas }\end{array}$ & $\begin{array}{c}\text { North Sea } \\
\text { natural gas }\end{array}$ & $\begin{array}{c}\text { Italian NG } \\
\text { regulation limits }\end{array}$ & $\begin{array}{c}\text { German NG } \\
\text { regulation limits }\end{array}$ & $\begin{array}{c}\text { Sweden NG } \\
\text { regulation limits }\end{array}$ \\
\hline $\mathrm{CH}_{4}[\%$ vol $]$ & $35 \div 65$ & $53 \div 70$ & 87 & n.a. & n.a. & $95 \div 99$ \\
$\mathrm{H}_{2}[\%$ vol $]$ & $0 \div 3$ & n.a. & n.a. & n.a. & $<5$ & n.a. \\
$\mathrm{CO}_{2}[\%$ vol $]$ & $15 \div 50$ & $30 \div 47$ & 1.2 & $<3$ & $<6$ & sum up to $5 \%$ \\
$\mathrm{O}_{2}[\%$ vol $]$ & $0 \div 5$ & 0 & 0 & $<0.6$ & $<3$ & n.a. \\
$\mathrm{N}_{2}[\%$ vol $]$ & $5 \div 40$ & 0.2 & 0.3 & n.a. & $<4.6$ & n.a. \\
$\mathrm{H}_{2} \mathrm{~S}[\mathrm{ppm}]$ & $<100$ & $<100$ & 0 & n.a. & $<30$ & $<23$ \\
$\mathrm{~S}\left[\mathrm{mg} / \mathrm{Nm}^{3}\right]$ & n.a. & n.a. & 0 & & & \\
\hline
\end{tabular}

on the WGS reaction. On the other hand, the dilution with an inert could be favourable by the point of view of safety.

However, hydrogen production from biogas is presently poorly applied in real plants, since biogas is typically directly used as a fuel in power generation units located close to the biogas production facilities. Due to such limitation this option is not further addressed explicitly in this work. As already mentioned, several other technologies could be chosen to produce hydrogen from gaseous or liquid hydrocarbons, based on different principles (e.g. steam-iron and chemical looping processes, plasma reforming, photoproduction, ...). Nevertheless, they are not used in commercial application and therefore not addressed here.

\section{Large scale steam reforming of natural gas}

The first option addressed in this work is also the most widespread type of plant nowadays used for the production of large quantities of hydrogen. It is based on steam reforming of natural gas, typically carried out in fired tubular reforming (FTR) plants. This is the generally the most competitive technology for plant capacity up to approximately $250,000 \mathrm{Nm}^{3}$ of $\mathrm{H}_{2}$ per hour.

A typical layout of a large scale steam reforming plant is shown in Fig. 2, later referred to as Configuration 1, where main components and streams are evidenced.

Even if this kind of plant is essentially designed for $\mathrm{H}_{2}$ production, it also usually shows a consistent export of superheated steam (typically used by adjacent industrial processes), produced by heat recovery from hot gas streams.

The main chemical reactor (C) is the reformer, which requires a heat source due to the strongly endothermic balance of reaction (1). In order to grant optimal mechanical and thermal resistance of the materials, the reaction takes place in catalyst filled vertical tubes that are externally irradiated by a flame. The catalyst is usually Ni-based in form of pellets or powders, which may have specific manipulation and handling hazards (e.g. toxicity); more active noble metals could be adopted as catalysts, but $\mathrm{Ni}$ is preferred due to its relatively lower cost. A pre-reforming stage (B) can be introduced in case of presence of heavier hydrocarbons in the feeding stream $\left(\mathrm{C}_{2+}\right.$ hydrocarbons, that can reach up to $10 \%$ in common natural gas). The aim of this reactor is to decompose the larger hydrocarbon chains in $\mathrm{CH}_{4}, \mathrm{CO}$ and $\mathrm{H}_{2}$. This reactor is usually adiabatic and works at lower temperatures in order to reduce the risk and amount of solid carbon (coke) formation, which is easier from highly reactive heavy hydrocarbons molecules
[19]. Also this reaction is generally enhanced by aluminasupported, Ni-based catalysts.

The catalysts are very sensible to sulphur. Therefore the NG feedstock must be treated in a desulfurization unit (DSU), generally based on a two stage process starting with a catalytic hydrogenation of all the sulphur-organic compounds over a catalyst (typically Co-Mo at $290-370{ }^{\circ} \mathrm{C}$ ) to form $\mathrm{H}_{2} \mathrm{~S}$. The second step is $\mathrm{H}_{2} \mathrm{~S}$ scrubbing by a $\mathrm{ZnO}$ bed (at about $\left.340-390{ }^{\circ} \mathrm{C}\right)$.

The reformer is usually operated at high temperatures (about $800-920^{\circ} \mathrm{C}$ ). Most industrial plants are operated at high pressures (up to 40 bar), despite the negative influence of the pressure on the reforming reaction equilibrium, in order to obtain pressurized $\mathrm{H}_{2}$ and reduce the size of the reactor. Another relevant control parameter is the steam to carbon ratio (S/C), defined as the molar ratio $\mathrm{H}_{2} \mathrm{O} / \mathrm{CH}_{4}$, which is usually maintained in the range $2.5 \div 3$ in order to avoid carbon formation on the catalyst.

Downstream the reformer, a further section is dedicated to the water gas shift (WGS) reaction (2). To achieve higher CO conversion into hydrogen, two reactors with different catalysts are commonly used in series (D). The HT-WGS reactor usually relies on an iron-chromium-based catalyst that works at about $400{ }^{\circ} \mathrm{C}$; on the other hand, the LT-WGS catalyst is generally $\mathrm{Cu}-\mathrm{Zn}$ based and works at lower temperatures $\left(200-300^{\circ} \mathrm{C}\right)$.

Finally, a purification process is used to remove the large amount of impurities $\left(\mathrm{CO}_{2}, \mathrm{CO}, \mathrm{N}_{2}\right)$ contained in the syngas. Large plants usually adopt a pressure-swing adsorption (PSA) system, based on a multiple adsorption bed system (molecular sieves of suitable pore size) where the adsorption and release of impurities is governed by periodical pressure changes (the so-called pressure swing) on the beds. The number of PSA vessels could be from 8 to 12 . The large quantity of off-gas released by the beds during the release phase of impurities is stored in a surge drum (F) and used as secondary fuel for the reformer furnace. In some cases, the LT-WGS can be removed and a larger fraction of residual $\mathrm{CO}$ will be contained in the off-gas and finally burned in order to provide the reaction heat; nevertheless, in this case the PSA section has to be designed for higher off-gas flows.

A summary of common streams conditions is presented in Table 4.

Inlet natural gas is pressurized (assuming an isoentropic efficiency of 0.72 ) to common operation conditions; steam reforming reactions are favoured at low pressures, anyway this technology is usually operated under pressure in order to 


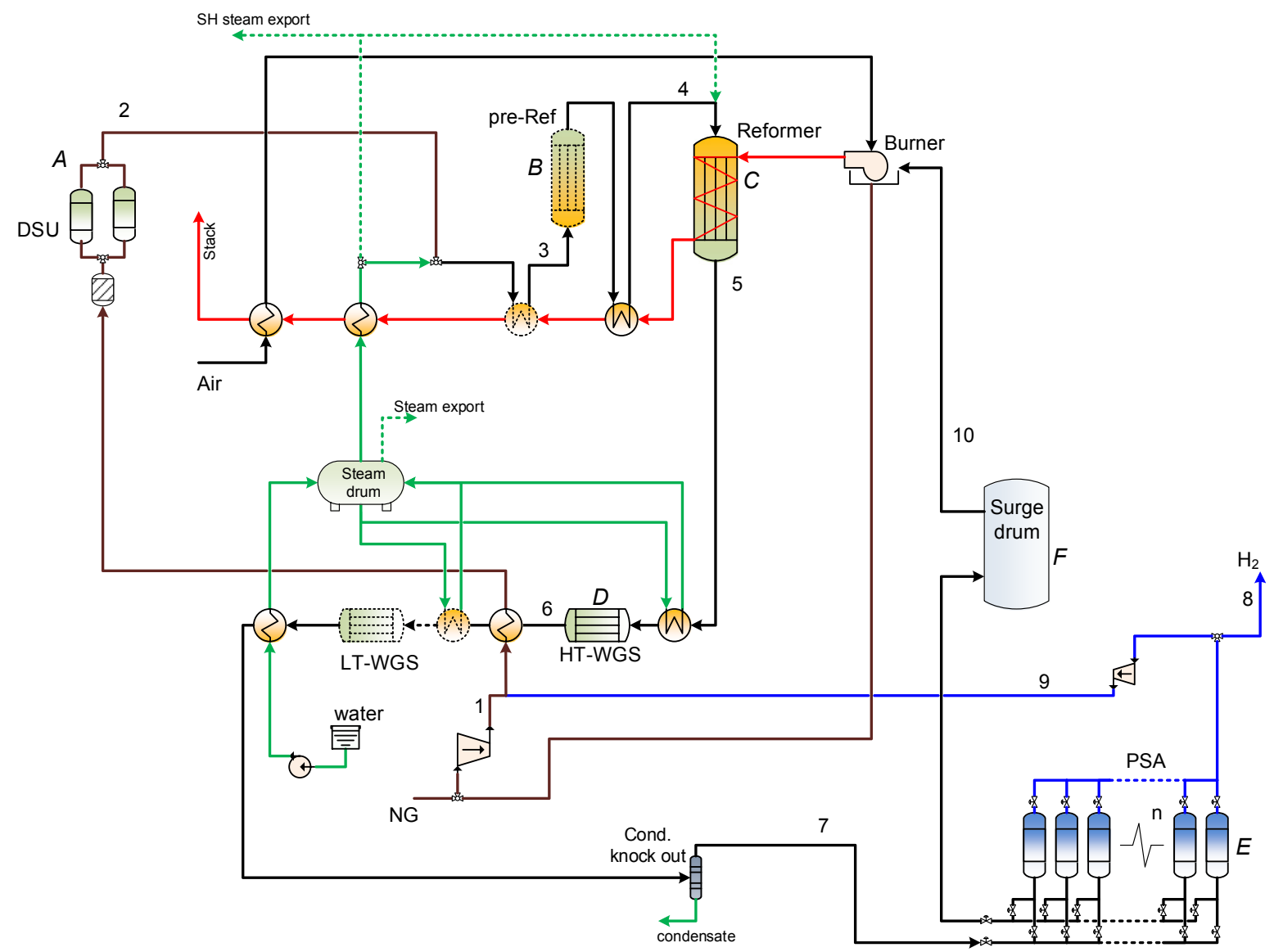

Fig. 2 - Configuration 1 - Large scale steam reforming of natural gas.

Table 4 - Configuration 1 - Large scale SR - Operating conditions.

\begin{tabular}{|c|c|c|c|c|c|c|c|c|c|c|c|c|}
\hline \multirow[t]{2}{*}{ Point } & \multirow{2}{*}{$\frac{\mathrm{P}}{\left[\mathrm{bar}_{\mathrm{a}}\right]}$} & \multirow{2}{*}{$\frac{\mathrm{T}}{\left[{ }^{\circ} \mathrm{C}\right]}$} & \multirow{2}{*}{$\frac{F}{\left.{ }^{a}\right]}$} & \multicolumn{8}{|c|}{ Composition (\% molar) } & \multirow[t]{2}{*}{ Notes } \\
\hline & & & & $\mathrm{C}_{\mathrm{x}} \mathrm{H}_{\mathrm{y}}$ & $\mathrm{H}_{2}$ & $\mathrm{CO}$ & $\mathrm{CO}_{2}$ & $\mathrm{H}_{2} \mathrm{O}$ & $\mathrm{O}_{2}$ & $\mathrm{~N}_{2}$ & $\mathrm{H}_{2} \mathrm{~S}$ & \\
\hline 1 & $17 \div 37$ & $120 \div 150$ & $0.37 \div 0.41$ & $94 \div 100$ & - & - & $<2$ & - & $<0.1$ & $<5$ & $<1$ & Flammable \\
\hline 2 & $16 \div 36$ & $300 \div 400$ & $0.37 \div 0.41$ & $94 \div 100$ & $<3$ & - & $<2$ & - & $<0.1$ & $<5$ & $<1 \mathrm{ppm}$ & Flammable \\
\hline 3 & $16 \div 36$ & $400 \div 600$ & $1.4 \div 2$ & $20 \div 28$ & $<1$ & - & $<1$ & $72 \div 80$ & - & $<1$ & $<1 \mathrm{ppm}$ & Flammable \\
\hline 4 & $16 \div 36$ & $600 \div 700$ & $1.5 \div 2.1$ & $16 \div 22$ & $6 \div 11$ & $<0.1$ & $1 \div 3$ & $68 \div 72$ & - & $<1$ & $<1 \mathrm{ppm}$ & Flammable \\
\hline 5 & $13 \div 33$ & $800 \div 920$ & $2.1 \div 2.8$ & $0.4 \div 5$ & $45 \div 48$ & $7 \div 9$ & $5 \div 7$ & $35 \div 39$ & - & $<1$ & $<1 \mathrm{ppm}$ & Flammable/toxic \\
\hline 6 & $11 \div 31$ & $400 \div 440$ & $2.1 \div 2.8$ & $0.4 \div 5$ & $51 \div 55$ & $1 \div 3$ & $11 \div 13$ & $29 \div 33$ & - & $<1$ & $<1 \mathrm{ppm}$ & Flammable/toxic \\
\hline 7 & $10 \div 30$ & $30 \div 60$ & $1.4 \div 1.9$ & $0.6 \div 7$ & $73 \div 79$ & $2 \div 4$ & $16 \div 18$ & $0.1 \div 0.9$ & - & $<1$ & $<1 \mathrm{ppm}$ & Flammable/toxic \\
\hline 8 & $9 \div 29$ & $30 \div 60$ & $0.9 \div 1.4$ & $<0.1$ & Gr. 5.0 & $<0.2$ & $<0.2$ & $<0.1$ & - & $<0.2$ & - & Flammable \\
\hline 9 & $10 \div 37$ & $30 \div 60$ & $<0.02$ & $<0.1$ & Gr. 5.0 & $<0.2$ & $<0.2$ & $<0.1$ & - & $<0.2$ & - & Flammable \\
\hline 10 & $1 \div 1.5$ & $10 \div 40$ & $0.5 \div 0.8$ & $2 \div 17$ & $21 \div 42$ & $6 \div 10$ & $39 \div 60$ & $0.3 \div 3$ & - & $<0.6$ & - & Flammable/toxic \\
\hline
\end{tabular}

Bold: assumptions from literature data.

a All flows are in $\mathrm{Nm}^{3} / \mathrm{h}$ relative to a production of $1 \mathrm{Nm}^{3} / \mathrm{h}$ of hydrogen.

satisfy the requirement of the downstream users. Hydrogen addition for desulphurization is calculated in order to obtain about $2 \div 5 \%$ vol of hydrogen at the inlet of hydrogenation unit. Pre-reformer and reformer units are calculated as equilibrium reactors, while WGS is modelled as a stoichiometric reactor (assuming a 90\% conversion of CO) and the steam-to-carbon ratio at reformer inlet is 2.8 [19]. PSA is supposed to recover about $90 \%$ of the inlet hydrogen, while the residual is collected with the surge and burned in the furnace to sustain endothermic reactions. Reasonable pressure drops are also considered in the system [20].

Table 5 shows a comparison of components size. For large plants, usually coupled with refinery or chemical industries, the size of the reformer reactor can be more than $10 \mathrm{~m}$ in height and width; moreover also the PSA sections and the surge drum typically feature large dimensions. 
Table 5 - Configuration 1 - Large scale SR - Indicative relative size of relevant components.

\begin{tabular}{lll}
\hline Config. ref. & \multicolumn{1}{c}{ Description } & Relative size \\
\hline A & Desulfurization unit & + \\
B & Pre-reformer & ++ \\
C & Reformer & $++/+++$ \\
D & High temperature WGS & $+/++$ \\
E & Pressure swing adsorption & +++ \\
F & Surge drum & +++ \\
\hline
\end{tabular}

\section{Small to medium scale steam reforming of natural gas with} CO-PrOx

In applications requiring low pressure syngas with high content of hydrogen the solution described in this configuration would meet the needs, and is significantly widespread in the real practice. Typical users of hydrogen in such conditions may be fuel cell types where the constraints on the composition of the reformate gas are mainly related to the content of carbon monoxide and sulphur components. For instance, in low temperature fuel cells (as in Polymer Electrolyte Membrane) the limitations for $\mathrm{CO}$ content are typically below 10-20 ppmvd.

With respect to configuration 1, the differences are due to the necessity of simplicity related to the smaller scale, so that (i) the method to purify the produced hydrogen stream after the steam reforming and WGS section is the CO preferential oxidation (CO-PrOX); and (ii) natural gas desulphurization ahead the reforming section is typically carried out at low temperature.

A PrOx reactor typically consists of a catalyst bed where the fuel gas, containing hydrogen and carbon monoxide, is introduced together with a small amount of oxygen or air. Carbon oxide is then oxidized to $\mathrm{CO}_{2}$ thanks to the catalyst, operating in a preferential way with respect to hydrogen. The CO content can therefore be reduced to few ppm.

In this process the two reactions:

$\mathrm{CO}+\frac{1}{2} \mathrm{O}_{2} \rightarrow \mathrm{CO}_{2} \quad \Delta \mathrm{H}_{298 \mathrm{~K}}^{\circ}=-283 \mathrm{~kJ} / \mathrm{mol}$

and:

$\mathrm{H}_{2}+\frac{1}{2} \mathrm{O}_{2} \rightarrow \mathrm{H}_{2} \mathrm{O} \quad \Delta \mathrm{H}_{298 \mathrm{~K}}^{\circ}=-241 \mathrm{~kJ} / \mathrm{mol}$

are in competition. Therefore, the catalyst selectivity is fundamental in order to reduce the hydrogen consumption. Metal oxides $\left(\mathrm{CoO}_{\mathrm{x}}, \mathrm{CuO}-\mathrm{CeO}_{2}\right)$ and supported noble metal (Ru, Pt and Rh) catalysts have currently suitable characteristics. Each of this catalyst has an optimal operation temperature range that can vary from about $80^{\circ} \mathrm{C}$ to more than $250^{\circ} \mathrm{C}$.

As shown in Fig. 3, later referred to as Configuration 2, this layout differs from the large scale steam reforming plant just in the desulfurization and in the purification sections. In this case only NG from the grid is burned in the reformer to sustain the reaction; the additional heat from $\mathrm{CO}$ oxidation is recovered by steam production.

Ahead the reforming section, desulfurization is mandatory due to the sensitivity of reforming catalysts to sulphur presence in the feeding. Due to the smaller sizes, a cold desulphurization based on adsorption can be adopted; usually some activated carbon beds are cyclically operated in adsorption and regeneration mode. Operating temperature are usually close to room temperature during adsorption. The regeneration phase requires an air stream and possibly a low amount of superheated steam to enhance the stripping process.

Table 6 shows a summary of plant operating conditions, and Table 7 evidences the relative size of main components. Pressurized natural gas is fed to the system (see assumptions for Configuration 1), but cold desulphurization (adsorption) needs no additional hydrogen recycle. Air injection is calculated to match the hydrogen purity requirements.

\section{Small to medium scale steam reforming of natural gas with PSA}

This third layout is an alternative option, very similar to the previous one and significantly diffused in practical applications. Due to the small or medium scale of the plant, the desulfurization technology adopted is again a cold one, based on adsorption. On the other hand, if the hydrogen purity requirements are not very strict, a small PSA purification system is appropriate; moreover, as mentioned in the large scale layout description, this solution allows to design the WGS section with both LT and HT reactors or with a single HT WGS, simplifying the control system and the flow scheme. The offgas produced by hydrogen purification contains a large amount of fuel (mainly CO) and therefore it is convenient to recycle this stream in the reformer reactor burners. Fig. 4 shows the resulting layout, which is later referred to as Configuration 3.

Tables 8 and 9 summarize common operational conditions and main components relative size for this kind of plant. Assumptions for this case are the same for the previous one (Configuration 2), considering an hydrogen recovery efficiency of 0.9 for the PSA system.

\section{Autothermal reforming}

Autothermal steam reforming (ATR) differs from the previous described process due to the adoption of another heat source for the reforming reaction, provided by the combustion of a fraction of the processed fuel. The hydrocarbon feed is introduced in the reactor and mixed with steam and a substoichiometric amount of oxygen or air. Then, the ATR reactor consists of three different sections: combustion, thermal and catalytic zone. In the first section of the reactor (combustion zone), a turbulent flame provides heat for the subsequent endothermic reaction. In the subsequent zone (thermal zone), the steam reforming and water gas shift reaction start due to the high temperature; finally, reactions are completed in the third zone on a catalytic bed. The catalyst is usually alumina-supported Ni.

The resulting plant layout is shown in Fig. 5 and is later referred to as Configuration 4.

This system can work at much higher pressures (up to about $18 \div 70$ bar) than the classical fired tubular steam reforming because of the absence of thermal and mechanical stresses in the reactor tubes. The operating temperatures are 


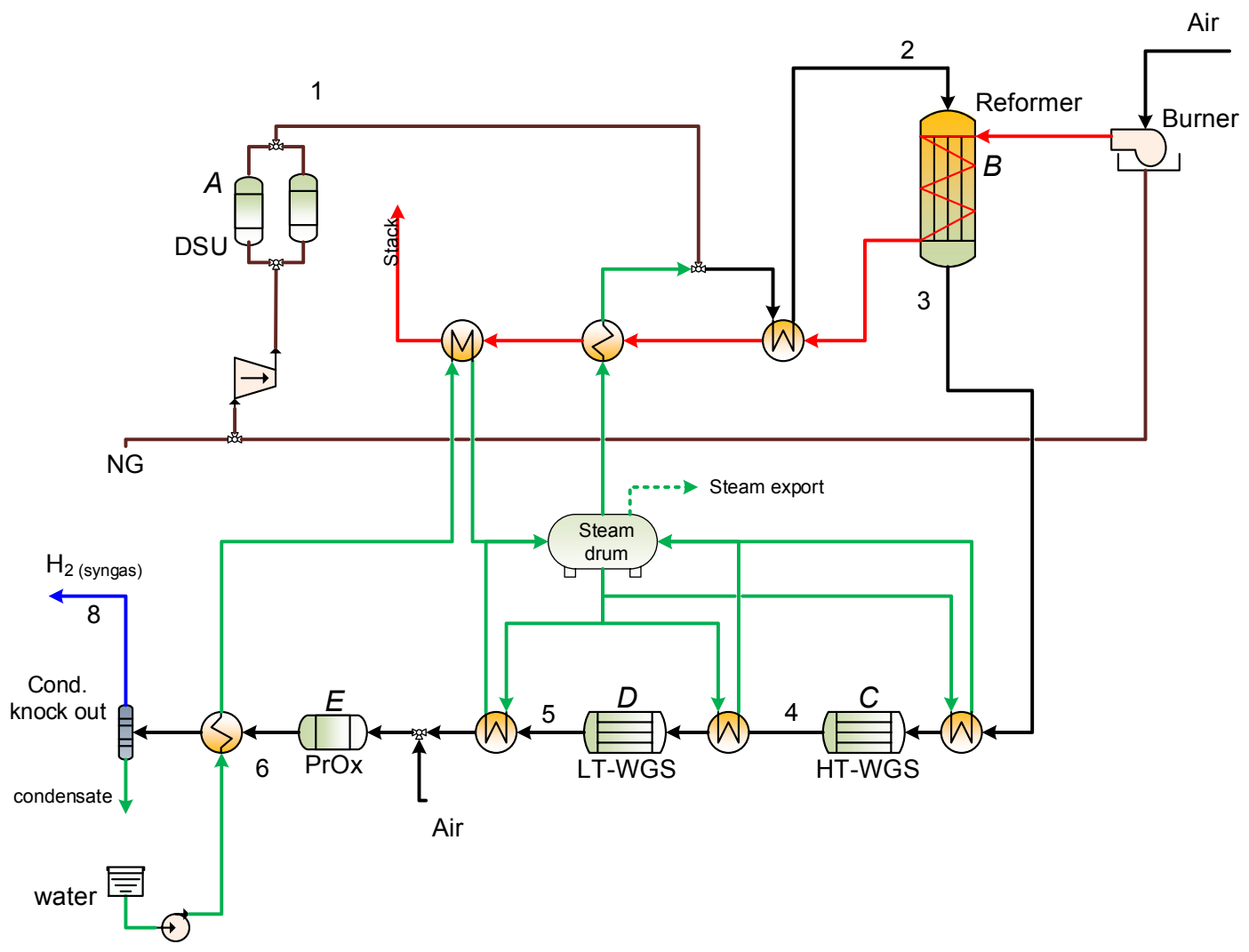

Fig. 3 - Configuration 2 - Steam reforming of natural gas with CO-PrOx.

also much higher (above $1000^{\circ} \mathrm{C}$ ) and good conversion can be reached with lower steam to carbon ratios. Typically, the resulting $\mathrm{H}_{2} / \mathrm{CO}$ ratio is lower than in the steam reforming process.

Air feeding is economically convenient in comparison with oxygen one, but leads to a large amount of nitrogen in the product that has to be removed (with the exception of hydrogen used for ammonia production).

The resulting plant is more compact than the tubular steam reformer, but when using an oxygen feeding it requires a rather complex air separation unit (ASU). In the following we consider the case of a large scale application, with oxygen-fed ATR.
In Tables 10 and 11 , common operational conditions and main components relative size of this kind of plants are summarized. Assumptions for autothermal reforming are very similar to the SMR ones (see Configuration 1);

Table 7 - Configuration 2 - SR with PrOX - Indicative relative size of relevant components.

\begin{tabular}{llc}
\hline Config. ref. & \multicolumn{1}{c}{ Description } & Relative size \\
\hline A & Desulphurization unit & + \\
B & Reformer & $++/+++$ \\
C & High-temperature WGS & $+/++$ \\
D & Low-temperature WGS & $+/++$ \\
E & Preferential oxidation reactor & + \\
\hline
\end{tabular}

Table 6 - Configuration 2 - SR with PrOX - Operating conditions.

\begin{tabular}{|c|c|c|c|c|c|c|c|c|c|c|c|c|}
\hline \multirow[t]{2}{*}{ Point } & \multirow{2}{*}{$\frac{\mathrm{P}}{\left[\mathrm{bar}_{\mathrm{a}}\right]}$} & \multirow{2}{*}{$\frac{\mathrm{T}}{\left[{ }^{\circ} \mathrm{C}\right]}$} & \multirow{2}{*}{$\frac{F}{\left[{ }^{a}\right]}$} & \multicolumn{8}{|c|}{ Composition (\% molar) } & \multirow[t]{2}{*}{ Notes } \\
\hline & & & & $\mathrm{C}_{\mathrm{x}} \mathrm{H}_{\mathrm{y}}$ & $\mathrm{H}_{2}$ & $\mathrm{CO}$ & $\mathrm{CO}_{2}$ & $\mathrm{H}_{2} \mathrm{O}$ & $\mathrm{O}_{2}$ & $\mathrm{~N}_{2}$ & $\mathrm{H}_{2} \mathrm{~S}$ & \\
\hline 1 & $16 \div 36$ & $20 \div 40$ & $0.37 \div 0.41$ & $94 \div 100$ & - & - & $<2$ & - & $<0.1$ & $<5$ & $<1 \mathrm{ppm}$ & Flammable \\
\hline 2 & $16 \div 36$ & $500 \div 700$ & $1.4 \div 2$ & $20 \div 28$ & $<1$ & - & $<1$ & $72 \div 80$ & - & $<1$ & $<1 \mathrm{ppm}$ & Flammable \\
\hline 3 & $13 \div 33$ & $800 \div 920$ & $2.1 \div 2.8$ & $0.4 \div 5$ & $45 \div 48$ & $7 \div 9$ & $5 \div 7$ & $35 \div 39$ & - & $<1$ & $<1 \mathrm{ppm}$ & Flammable/toxic \\
\hline 4 & $11 \div 31$ & $400 \div 440$ & $2.1 \div 2.8$ & $0.4 \div 5$ & $51 \div 55$ & $1 \div 3$ & $11 \div 13$ & $29 \div 33$ & - & $<1$ & $<1 \mathrm{ppm}$ & Flammable/toxic \\
\hline 5 & $9 \div 29$ & $100 \div 300$ & $2.1 \div 2.8$ & $0.4 \div 5$ & $52 \div 58$ & $<2$ & $12 \div 15$ & $26 \div 30$ & - & $<1$ & $<1 \mathrm{ppm}$ & Flammable/toxic \\
\hline 6 & $8 \div 28$ & $80 \div 300$ & $2.2 \div 2.9$ & $0.2 \div 4$ & $48 \div 54$ & $<10 \mathrm{ppm}$ & $11 \div 16$ & $25 \div 31$ & - & $3 \div 4$ & $<1 \mathrm{ppm}$ & Flammable \\
\hline 7 & $7 \div 27$ & $30 \div 60$ & $1.4 \div 2.1$ & $0.5 \div 6$ & $70 \div 76$ & $<10 \mathrm{ppm}$ & $16 \div 21$ & $0.1 \div 0.9$ & - & $4 \div 5$ & $<1 \mathrm{ppm}$ & Flammable \\
\hline
\end{tabular}

Bold: assumptions from literature data.

a All flows are in $\mathrm{Nm}^{3} / \mathrm{h}$ relative to a production of $1 \mathrm{Nm}^{3} / \mathrm{h}$ of hydrogen. 


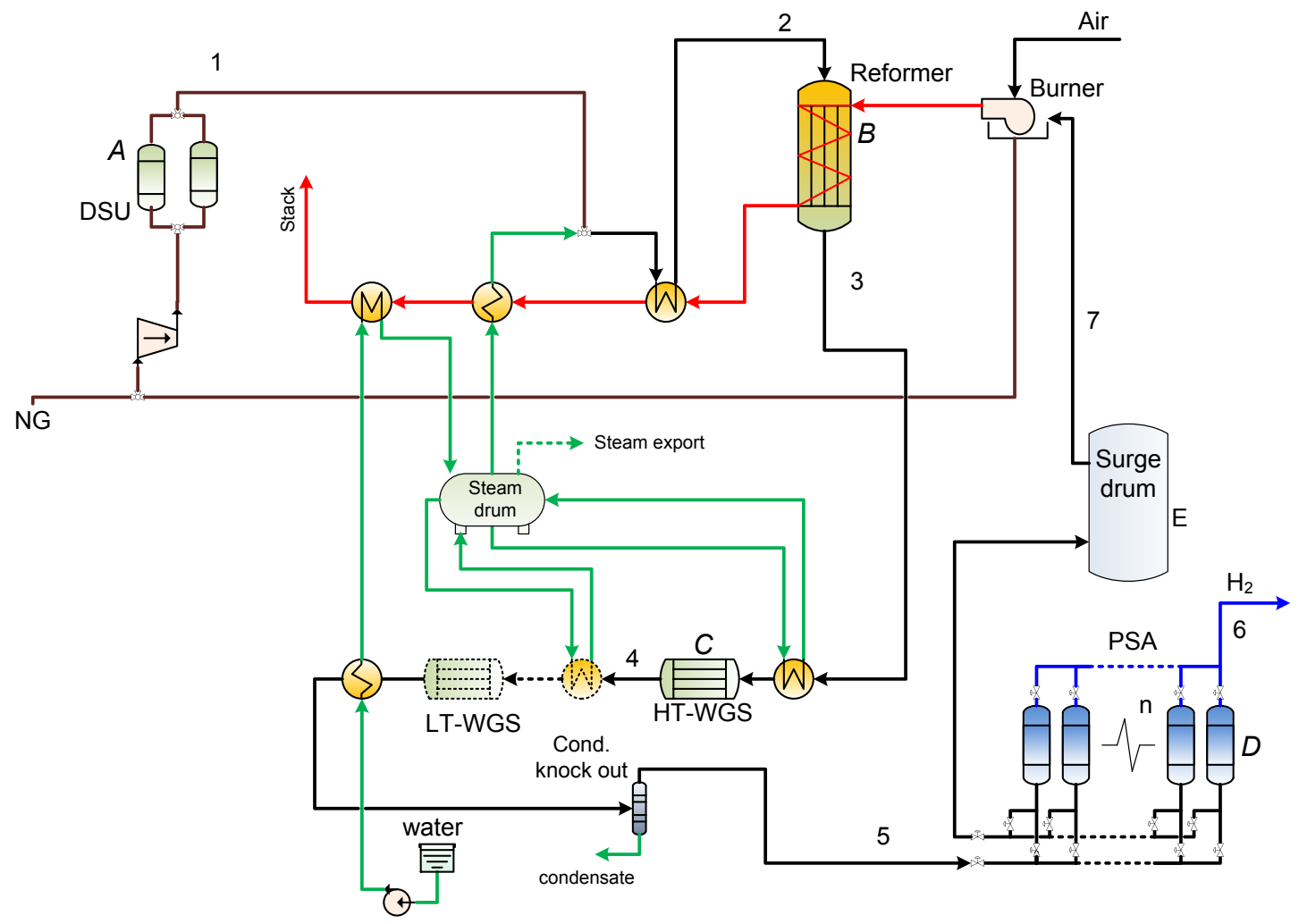

Fig. 4 - Configuration 3 - Steam reforming of natural gas with PSA.

nevertheless, main reactor temperature is higher and pure oxygen stream is calculated so that combustion would compensate steam reforming reaction duty (i.e. total reactor duty is null). Pure oxygen steam is produced by an ASU and purity is assumed accordingly.

\section{Partial oxidation}

The partial oxidation (POx) is another major commercial route for hydrogen production. This process is based on a combined feeding of fuel and oxygen (or air), theoretically without steam addition, in proportions that grant the conversion in a mixture of $\mathrm{H}_{2}$ and $\mathrm{CO}$, according to reaction (3). However, water has to be fed in the process in order to sustain the pre-reforming and the WGS reactions if required.

The ratio of oxygen to carbon $(\mathrm{O} / \mathrm{C})$ is controlled in order to maximize the yield of $\mathrm{CO}$ and $\mathrm{H}_{2}$, while maintaining an acceptable level of $\mathrm{CO}_{2}$ and residual methane. The overall process is exothermic and can be carried out catalytically or not. This technology differs from the previous ones because of the absence of a specific burning zone; the combustion takes place in the catalytic zone together with the reforming reactions. Moreover it can be operated without steam addition.

Table 9 - Configuration 3 - SR with PSA - Indicative relative size of relevant components.

\begin{tabular}{llc}
\hline Config. ref. & \multicolumn{1}{c}{ Description } & Relative size \\
\hline A & Desulphurization unit & + \\
B & Reformer & $++/+++$ \\
C & High temperature WGS & $+/++$ \\
D & Pressure Swing Adsorption & +++ \\
E & Surge drum & +++ \\
\hline
\end{tabular}

Table 8 - Configuration 3 - SR with PSA - Operating conditions.

\begin{tabular}{|c|c|c|c|c|c|c|c|c|c|c|c|c|}
\hline \multirow[t]{2}{*}{ Point } & \multirow{2}{*}{$\frac{\mathrm{P}}{\left[\mathrm{bar}_{\mathrm{a}}\right]}$} & \multirow{2}{*}{$\frac{\mathrm{T}}{\left[{ }^{\circ} \mathrm{C}\right]}$} & \multirow{2}{*}{$\frac{F}{[a]}$} & \multicolumn{8}{|c|}{ Composition (\% molar) } & \multirow[t]{2}{*}{ Notes } \\
\hline & & & & $\mathrm{C}_{\mathrm{x}} \mathrm{H}_{\mathrm{y}}$ & $\mathrm{H}_{2}$ & $\mathrm{CO}$ & $\mathrm{CO}_{2}$ & $\mathrm{H}_{2} \mathrm{O}$ & $\mathrm{O}_{2}$ & $\mathrm{~N}_{2}$ & $\mathrm{H}_{2} \mathrm{~S}$ & \\
\hline 1 & $16 \div 36$ & $10 \div 40$ & $0.37 \div 0.41$ & $94 \div 100$ & - & - & $<2$ & - & $<0.1$ & $<5$ & $<1 \mathrm{ppm}$ & Flammable \\
\hline 2 & $16 \div 36$ & $500 \div 700$ & $1.4 \div 2$ & $20 \div 28$ & $<1$ & - & $<1$ & $72 \div 80$ & - & $<1$ & $<1 \mathrm{ppm}$ & Flammable \\
\hline 3 & $13 \div 33$ & $800 \div 920$ & $2.1 \div 2.8$ & $0.4 \div 5$ & $45 \div 48$ & $7 \div 9$ & $5 \div 7$ & $35 \div 39$ & - & $<1$ & $<1 \mathrm{ppm}$ & Flammable/toxic \\
\hline 4 & $11 \div 31$ & $400 \div 440$ & $2.1 \div 2.8$ & $0.4 \div 5$ & $51 \div 55$ & $1 \div 3$ & $11 \div 13$ & $29 \div 33$ & - & $<1$ & $<1 \mathrm{ppm}$ & Flammable/toxic \\
\hline 5 & $10 \div 30$ & $30 \div 60$ & $1.4 \div 1.9$ & $0.6 \div 7$ & $73 \div 79$ & $2 \div 4$ & $16 \div 18$ & $0.1 \div 0.9$ & - & $<1$ & $<1 \mathrm{ppm}$ & Flammable/toxic \\
\hline 6 & $9 \div 29$ & $30 \div 60$ & $0.9 \div 1.4$ & $<0.1$ & Gr. 5.0 & $<0.2$ & $<0.2$ & $<0.1$ & - & $<0.2$ & - & Flammable \\
\hline 7 & $1 \div 1.5$ & $10 \div 40$ & $0.5 \div 0.8$ & $2 \div 17$ & $21 \div 42$ & $6 \div 10$ & $39 \div 60$ & $0.3 \div 3$ & - & $<0.6$ & - & Flammable/toxic \\
\hline
\end{tabular}

Bold: assumptions from literature data.

a All flows are in $\mathrm{Nm}^{3} / \mathrm{h}$ relative to a production of $1 \mathrm{Nm}^{3} / \mathrm{h}$ of hydrogen. 


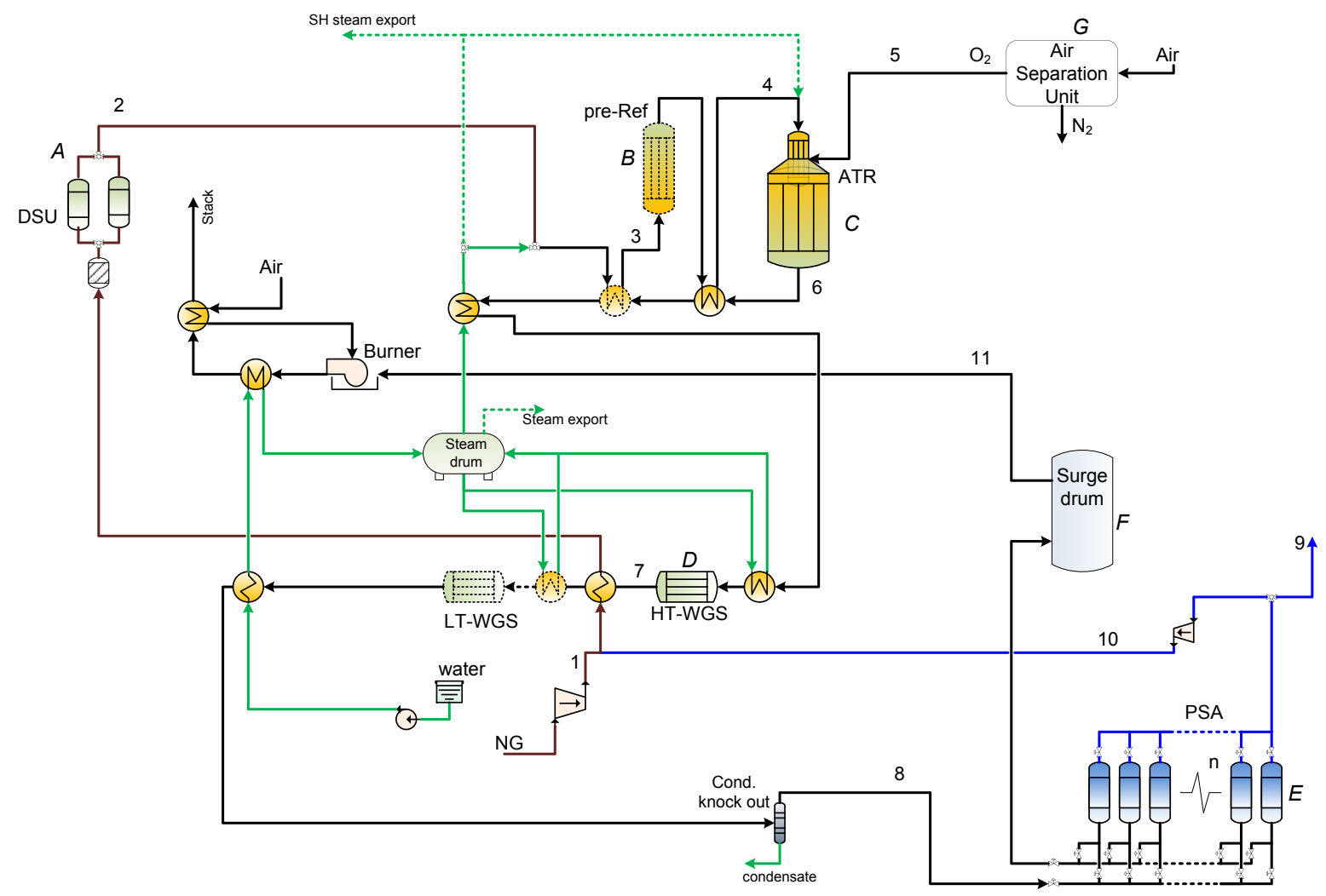

Fig. 5 - Configuration 4 - Autothermal reforming of natural gas.

Two solutions can be adopted: a catalytic and a noncatalytic one. The non-catalytic process (POX) operates at very high temperatures $\left(1100 \div 1500{ }^{\circ} \mathrm{C}\right)$ and can utilize any feedstock; the catalytic process (CPO or CPOX) works at lower temperatures $\left(600 \div 900{ }^{\circ} \mathrm{C}\right)$ and is suitable for lighter hydrocarbons. The first one has been commercially practiced for decades in refineries, in order to utilize the heavy residues (high in sulphur and heavy metals and otherwise very difficult to process). However, natural gas is the preferred feed from the technical point of view and can be used to produce hydrogen competitively in POX/CPO plants. The high-
Table 11 - Configuration 4 - ATR - Indicative relative size of relevant components.

\begin{tabular}{llc}
\hline Config. ref. & \multicolumn{1}{c}{ Description } & Relative size \\
\hline A & Desulphurization unit & + \\
B & Pre-reformer & ++ \\
C & ATR reactor & $++/+++$ \\
D & High-temperature WGS & $+/++$ \\
E & Pressure Swing Adsorption & +++ \\
F & Surge drum & +++ \\
G & Air separation unit & +++ \\
\hline
\end{tabular}

Table 10 - Configuration 4 - ATR - Operating conditions.

\begin{tabular}{|c|c|c|c|c|c|c|c|c|c|c|c|c|}
\hline \multirow[t]{2}{*}{ Point } & \multirow{2}{*}{$\frac{\mathrm{P}}{\left[\mathrm{bar}_{\mathrm{a}}\right]}$} & \multirow{2}{*}{$\frac{\mathrm{T}}{\left[{ }^{\circ} \mathrm{C}\right]}$} & \multirow{2}{*}{$\frac{F}{\left.{ }^{a}\right]}$} & \multicolumn{8}{|c|}{ Composition (\% molar) } & \multirow[t]{2}{*}{ Notes } \\
\hline & & & & $\mathrm{C}_{\mathrm{x}} \mathrm{H}_{\mathrm{y}}$ & $\mathrm{H}_{2}$ & $\mathrm{CO}$ & $\mathrm{CO}_{2}$ & $\mathrm{H}_{2} \mathrm{O}$ & $\mathrm{O}_{2}$ & $\mathrm{~N}_{2}$ & $\mathrm{H}_{2} \mathrm{~S}$ & \\
\hline 1 & $17 \div 70$ & $120 \div 150$ & $0.37 \div 0.41$ & $94 \div 100$ & - & - & $<2$ & - & $<0.1$ & $<5$ & $<1$ & Flammable \\
\hline 2 & $16 \div 69$ & $300 \div 400$ & $0.37 \div 0.41$ & $94 \div 100$ & $<3$ & - & $<2$ & - & $<0.1$ & $<5$ & $<1 \mathrm{ppm}$ & Flammable \\
\hline 3 & $16 \div 69$ & $500 \div 600$ & $1.4 \div 2.0$ & $30 \div 45$ & $<1$ & - & $<1$ & $51 \div 70$ & - & $<1$ & $<1 \mathrm{ppm}$ & Flammable \\
\hline 4 & $16 \div 69$ & $600 \div 700$ & $1.5 \div 2.1$ & $28 \div 43$ & $6 \div 11$ & $<0.1$ & $1 \div 3$ & $42 \div 65$ & - & $<1$ & $<1 \mathrm{ppm}$ & Flammable \\
\hline 5 & $20 \div 75$ & $160 \div 200$ & $0.3 \div 0.5$ & - & - & - & - & - & $92 \div 95$ & $2 \div 5$ & - & Highly reactive \\
\hline 6 & $12 \div 66$ & $950 \div 1050$ & $2.0 \div 2.8$ & $<1$ & $42 \div 45$ & $9 \div 15$ & $5 \div 10$ & $30 \div 35$ & - & $1 \div 2$ & $<1 \mathrm{ppm}$ & Flammable/toxic \\
\hline 7 & $10 \div 64$ & $400 \div 440$ & $2.0 \div 2.8$ & $<1$ & $50 \div 55$ & $2 \div 5$ & $15 \div 20$ & $20 \div 26$ & - & $1 \div 2$ & $<1 \mathrm{ppm}$ & Flammable/toxic \\
\hline 8 & $9 \div 63$ & $30 \div 60$ & $1.3 \div 1.8$ & $<1$ & $68 \div 75$ & $1 \div 3$ & $21 \div 28$ & $0.1 \div 0.9$ & - & $1 \div 2$ & $<1 \mathrm{ppm}$ & Flammable/toxic \\
\hline 9 & $9 \div 29$ & $30 \div 60$ & $0.9 \div 1.4$ & $<0.1$ & Gr 5.0 & $<0.2$ & $<0.2$ & $<0.1$ & - & $<0.2$ & - & Flammable \\
\hline 10 & $10 \div 37$ & $30 \div 60$ & $<0.02$ & $<0.1$ & Gr 5.0 & $<0.2$ & $<0.2$ & $<0.1$ & - & $<0.2$ & - & Flammable \\
\hline 11 & $1 \div 1.5$ & $10 \div 40$ & $0.5 \div 0.8$ & $2 \div 17$ & $21 \div 42$ & $6 \div 10$ & $39 \div 60$ & $0.3 \div 3$ & - & $<0.6$ & - & Flammable/toxic \\
\hline
\end{tabular}

Bold: assumptions from literature data.

a All flows are in $\mathrm{Nm}^{3} / \mathrm{h}$ relative to a production of $1 \mathrm{Nm}^{3} / \mathrm{h}$ of hydrogen. 


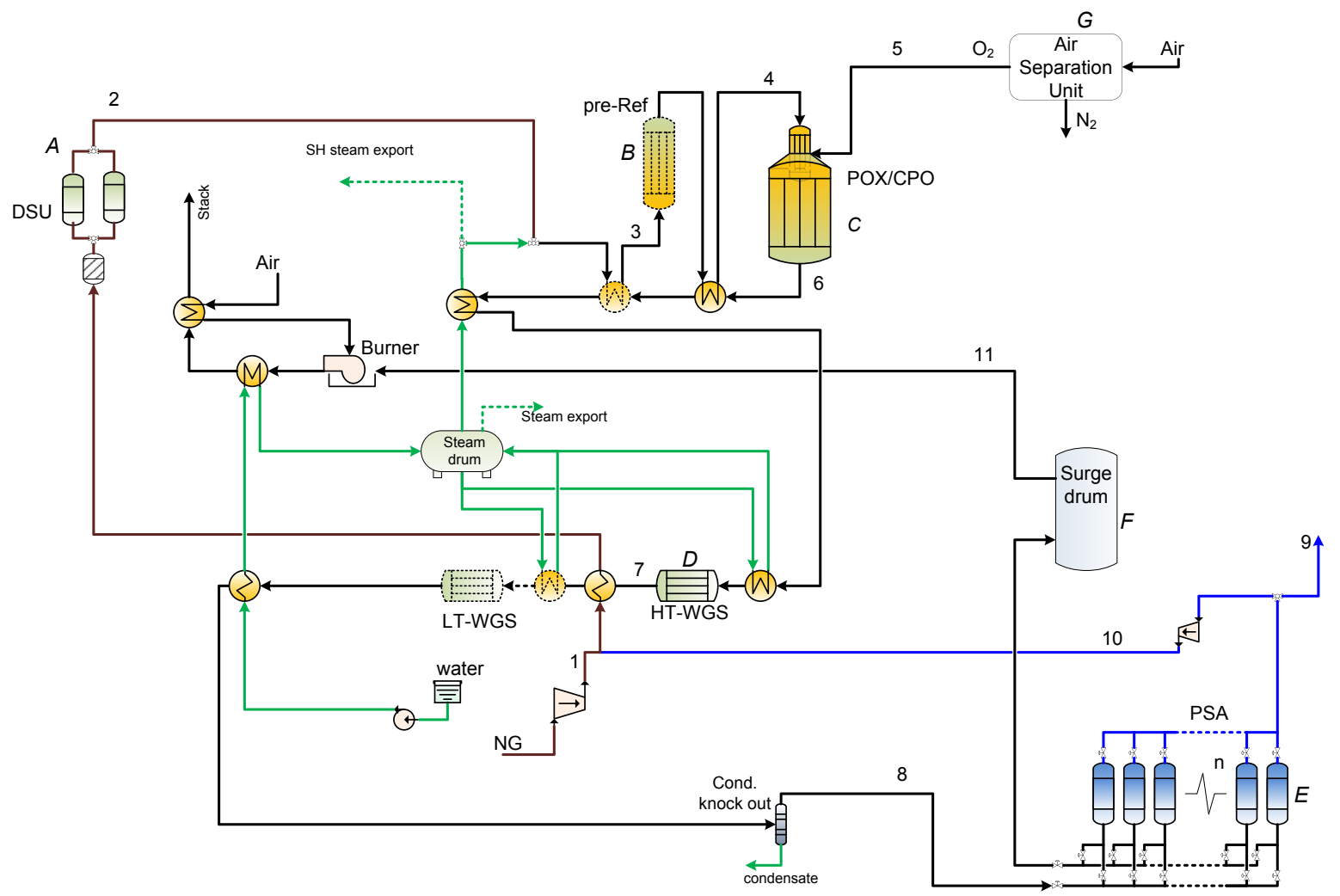

Fig. 6 - Configuration 5 - Partial oxidation of natural gas.

Table 12 - Configuration 5 - POX - Operating condition.

\begin{tabular}{|c|c|c|c|c|c|c|c|c|c|c|c|c|}
\hline \multirow[t]{2}{*}{ Point } & \multirow{2}{*}{$\frac{\mathrm{P}}{\left[\mathrm{bar}_{\mathrm{a}}\right]}$} & \multirow{2}{*}{$\frac{\mathrm{T}}{\left[{ }^{\circ} \mathrm{C}\right]}$} & \multirow{2}{*}{$\begin{array}{c}\mathrm{F} \\
{\left[{ }^{\mathrm{a}}\right]}\end{array}$} & \multicolumn{8}{|c|}{ Composition (\% molar) } & \multirow[t]{2}{*}{ Notes } \\
\hline & & & & $\mathrm{C}_{\mathrm{x}} \mathrm{H}_{\mathrm{y}}$ & $\mathrm{H}_{2}$ & $\mathrm{CO}$ & $\mathrm{CO}_{2}$ & $\mathrm{H}_{2} \mathrm{O}$ & $\mathrm{O}_{2}$ & $\mathrm{~N}_{2}$ & $\mathrm{H}_{2} \mathrm{~S}$ & \\
\hline 1 & $17 \div 37$ & $120 \div 150$ & $0.37 \div 0.41$ & $94 \div 100$ & - & - & $<2$ & - & $<0.1$ & $<5$ & $<1$ & - \\
\hline 2 & $16 \div 36$ & $300 \div 400$ & $0.37 \div 0.41$ & $94 \div 100$ & $<3$ & - & $<2$ & - & $<0.1$ & $<5$ & $<1 \mathrm{ppm}$ & - \\
\hline 3 & $16 \div 36$ & $300 \div 500$ & $0.61 \div 0.83$ & $42 \div 68$ & $<1$ & - & $<1$ & $33 \div 50$ & - & $<3$ & $<1 \mathrm{ppm}$ & - \\
\hline 4 & $16 \div 36$ & $600 \div 700$ & $0.65 \div 0.86$ & $20 \div 35$ & $15 \div 40$ & $1 \div 7$ & $3 \div 8$ & $20 \div 45$ & - & $<3$ & $<1 \mathrm{ppm}$ & Flammable \\
\hline 5 & $20 \div 45$ & $160 \div 200$ & $0.10 \div 0.14$ & - & - & - & - & - & $92 \div 95$ & $2 \div 5$ & - & Highly reactive \\
\hline 6 & $12 \div 32$ & $700 \div 1100$ & $0.95 \div 1.31$ & $<1$ & $30 \div 55$ & $10 \div 20$ & $2 \div 6$ & $15 \div 30$ & 0 & $<2$ & $<1 \mathrm{ppm}$ & Flammable/toxic \\
\hline 7 & $10 \div 30$ & $400 \div 440$ & $0.95 \div 2.8$ & $<1$ & $50 \div 55$ & $2 \div 5$ & $15 \div 20$ & $10 \div 20$ & - & $<2$ & $<1 \mathrm{ppm}$ & Flammable/toxic \\
\hline 8 & $9 \div 29$ & $30 \div 60$ & $0.82 \div 2.5$ & $<1$ & $68 \div 75$ & $1 \div 3$ & $21 \div 28$ & $0.1 \div 0.9$ & - & $<2$ & $<1 \mathrm{ppm}$ & Flammable/toxic \\
\hline 9 & $5 \div 15$ & $30 \div 60$ & $0.9 \div 1.4$ & $<0.1$ & Gr. 5.0 & $<0.2$ & $<0.2$ & $<0.1$ & - & $<0.2$ & - & Flammable \\
\hline 10 & $10 \div 37$ & $30 \div 60$ & $<0.02$ & $<0.1$ & Gr. 5.0 & $<0.2$ & $<0.2$ & $<0.1$ & - & $<0.2$ & - & Flammable \\
\hline 11 & $1 \div 1.5$ & $10 \div 40$ & $0.5 \div 0.8$ & $2 \div 17$ & $21 \div 42$ & $6 \div 10$ & $39 \div 60$ & $0.3 \div 3$ & - & $<0.6$ & - & Flammable/toxic \\
\hline
\end{tabular}

Bold: assumptions from literature data.

a All flows are in $\mathrm{Nm}^{3} / \mathrm{h}$ relative to a production of $1 \mathrm{Nm}^{3} / \mathrm{h}$ of hydrogen.

temperature stream at the reactor outlet can be a problem for the heat exchangers and has to be cooled.

In the catalytic section, a number of reactions take place (partial and complete combustion, steam reforming and water gas shift reactions) and typically reach the chemical equilibrium. An issue is the temperature control in the reactor that can locally exceed $1000^{\circ} \mathrm{C}$ due to the initial very high rate of reaction of partial and complete combustion (reaction (3)). Different solution for the catalyst (materials, shape, ...) are currently under development to improve the performances and the lifetime.
Table 13 - Configuration 5 - POX - Indicative relative size of relevant components.

\begin{tabular}{lll}
\hline Config. ref. & \multicolumn{1}{c}{ Description } & Relative size \\
\hline A & Desulphurization unit & + \\
B & Pre-reformer & ++ \\
C & Partial oxidation reactor & $++/+++$ \\
D & High-temperature WGS & $+/++$ \\
E & Pressure Swing Adsorption & +++ \\
F & Surge drum & +++ \\
G & Air separation unit & +++ \\
\hline
\end{tabular}


Both air and oxygen feeding solutions can be adopted, where the first one reduces the investment costs but generates nitrogen diluted hydrogen.

Fig. 6 shows the layout of a NG partial oxidation plant; the adopted configuration considers a pure oxygen feeding (with ASU). As evident, the conceptual layout is essentially identical to the ATR. This plant configuration is later labelled and referred to as Configuration 5.

Table 12 summarizes common operational conditions of a CPO plant. The values refer to a plant where both a prereforming unit and one or more WGS reactors are included, in order to process a heavier feedstock and to improve the conversion of $\mathrm{CO}$ to $\mathrm{H}_{2}$.

Assumptions for POX configuration are the same as for ATR system, whereas the differences consist of lower steamto-carbon rate (about 1) and reactor working temperature, due to different reaction schemes and catalysts.

In case of a plant that adopt the POX technology, no catalyst is present in the reactor; as a consequence, the temperature in the POX unit can reach values above $1300{ }^{\circ} \mathrm{C}$ that are required by the reaction as stated before. The outlet stream (6) has to be cooled with additional water before the heat exchangers in order to avoid damages. Water in stream 6 is required by the further steps of WGS and therefore fed upstream; in case of absence of $\mathrm{CO}$ converters, this kind of plants can be operated with a very low ratio ' $\mathrm{H}_{2} \mathrm{O}$ to carbon' at the POX/CPO reactor inlet, nominally in the range $0 \div 0.15$. The resulting ratio $\mathrm{H}_{2} / \mathrm{CO}$ is lower (about $1.6 \div 1.9$ ).

In all the cases, the ratio between the oxygen provided and the $\mathrm{CH}_{4}$ in the feeding at the reactor inlet is about $0.6 \div 0.8$ in order to grant the energy required by the endothermic reactions.

Table 13 presents a comparison of the relative size of main components.

\section{Production from solid fuels}

Solid fuels are largely available with limited costs and therefore represent a valid alternative to more conventional hydrogen sources (i.e. natural gas for steam reforming). Coal and biomass are the most reasonable solutions from this point of view; anyway, the processes described in the following can be applied to refinery scraps and other heavy residues, which up to now represent one of the most experimented application. The product is a synthesis gas (mixture of different species, among which $\mathrm{H}_{2}$ and $\mathrm{CO}$ ); it could be directly used in an integrated plant for electricity generation or has to be treated in order to obtain a pure hydrogen flow. This kind of plants can be classified among the large scale ones (above $20.000 \mathrm{Nm}^{3} / \mathrm{h}$ ) and their typical efficiencies (about $50 \div 75 \%$ ) are low in comparison with steam reforming technologies.

Two technologies are currently available to process solid fuels, gasification and pyrolysis, that are based on different physical principles.

Gasification involves non-catalytic partial oxidation according to a general reaction scheme in the form:

$\mathrm{C}_{\mathrm{n}} \mathrm{H}_{m}+\frac{\mathrm{n}}{2} \mathrm{O}_{2} \leftrightarrows \mathrm{nCO}+\frac{\mathrm{m}}{2} \mathrm{H}_{2}$ that proceeds together with other reactions that depends on the species present in the feeding (e.g. carbon complete and partial oxidation, steam reforming, water gas shift, methanation reactions, thermal decomposition). A substoichiometric oxidant feed is typical of this technology, as described further below. The ratio $\mathrm{H} / \mathrm{C}$ can vary in a wide range according to the specific fuel adopted and, as a consequence, influences the composition of the syngas product and the optimal operating conditions. Due to the impurities in the feeding that cannot be removed before the gasification (sulphur compounds, ash, heavy metals), the adoption of catalysts is impossible and the reactors are operated at high temperatures (above $900{ }^{\circ} \mathrm{C}$ ) in order to improve the reaction rate; as a consequence, the outlet composition is very similar to the thermodynamic equilibrium one. An efficiency loss is due to carbon particles (soot) formation that can be improved by local conditions in the reactor; this phenomenon could be avoided by a fast and strong mixing of the feeding streams that nevertheless is not an industrial practice due to technical issues. Other unwanted products are sulphur and nitrogen compounds that has to be removed to preserve downstream catalytic units and to reduce the environmental impact.

Different reactor configurations identify the currently available technologies, among which the main ones are:

- fixed bed, in which the solid feed has a slow downward motion due to gravity, while the gases (oxygen and water vapour) flow counter-current. The outlet gas temperature is usually low (about $500 \div 600^{\circ} \mathrm{C}$ ) while very high temperatures can be reached in the middle section of the reactor (above $1500{ }^{\circ} \mathrm{C}$ ). Operating pressures are in the range $25 \div 30$ bar. In this case the particle size of the feeding is not an issue (up to $50 \mathrm{~mm}$ in diameter particles are allowed).

- fluidized bed, in which the feeding gas flow forms a suspension of the solid particles in the reactor; the mixing of the reactants is very strong and the heat and mass exchange improved. In order to grant a correct operation of the system, the size of the particles must be controlled (up to $10 \mathrm{~mm}$ ) and a preliminary treatment of the solid charge could be required. In order to avoid melting and coalescence of the ashes that could cause the de-fluidization of the bed, operating temperatures are lower than the ones in fixed bed configuration (up to $1100^{\circ} \mathrm{C}$ for coal, up to $950{ }^{\circ} \mathrm{C}$ for biomass). Pressures up to 30 bar are tolerated. Limestone can be added directly in the reactor in order to remove the sulphur with high efficiency.

- entrained bed, in which the oxidant flow and the solid are fed in co-current from the top of the reactor; the residence time is very short (few seconds) and therefore high temperatures (above $1300^{\circ} \mathrm{C}$ ) are required to obtain the required conversion rate. In this case the thermal conditions are uniform along the reactor. Typical operating pressures are in the range $20 \div 80$ bar. The solid feed has to be fine-grained (hundreds of micron in diameter); in practice, also liquid or gaseous feeding could be treated with this technology.

Among the described solutions, the one typically applied in coal and biomass gasification is the entrained bed due to its higher conversion rate, fuel flexibility and control simplicity; it 
requires a preliminary milling of the solid feed and an efficient heat recovery from the high temperature products.

Either pure oxygen or air can be adopted as oxidant flow. In the first case, plant components are smaller and a lower thermal input (i.e. hydrocarbon feed consumption) in the reactor is required due to the absence of the large amount of nitrogen that the air solution implies. However, the production of pressurized pure hydrogen is a energy intensive process and a significant fraction of the plant consumptions; this is anyway the most common solution.

Pyrolysis differs from gasification due to the absence of any oxidant directly fed to the reactor; indeed, the solid feed is thermally decomposed. Conventional pyrolysis works at $700 \div$ $900{ }^{\circ} \mathrm{C}$ and its major products are char and syngas. It's a process currently adopted for waste and biomass treatment. The required input of energy is typically applied indirectly, through the walls of the reactor; anyway the pyrolysis process could take place into gasification reactors, too. In fact, after the complete oxidant consumption in the first gasification section, the reaction proceeds through thermal decomposi-tion in a oxidant-free zone of the reactor.

\section{Gasification}

The gasification plant scheme (Fig. 7, later referred to as Configuration 6) described in this chapter is an example of the most common technology for coal gasification, but it can be applied with minor changes to any of the previously listed feedstock, including refinery residues which are probably the most frequent fuel used in nowadays existing large-scale plants.
A milling or fuel preparation section is usually included before the reactor to reach the particle size required by the gasification process. Two solutions can be adopted to feed the solid into the reactor: a discontinuous "lock-hoppers" system or a continuous "water slurry" system. In the first case the solid is put into a hopper that is pressurized with a gas (usually nitrogen) and then discharged into the reactor; the second technology feeds a mixture of pulverized solid fuel and water ("slurry"). The addition of nitrogen or water is useful for maximum temperature control.

As mentioned before, the reactor can be fed either with air or pure oxygen; Fig. 7 shows the oxygen case in order to evidence the presence of the plant section required for oxygen production (ASU).

A critical plant section is the one downstream the gasification reactor, where the products are progressively cooled down. Different solutions can be adopted. First of all, the gas products can be cooled (down to about $900{ }^{\circ} \mathrm{C}$ ) in a radiative heat exchanger ("syngas coolers"); the high temperature and the high sulphur content in the stream are not compatible with a traditional convective heat exchanger. A cheaper solution is to dilute the products with cold gas flow recirculated from a downstream section ("syngas quench"). Otherwise, cooling can be carried out by liquid water injection ("water quench") up to saturation, resulting in a more effective process thanks to the high water vaporization heat, with a larger temperature drop; on the other hand, this is a drawback for the subsequent heat recovery and steam production (yielding a lower steam pressure). After this first cooling step, a second step is carried out by traditional convective heat exchangers.

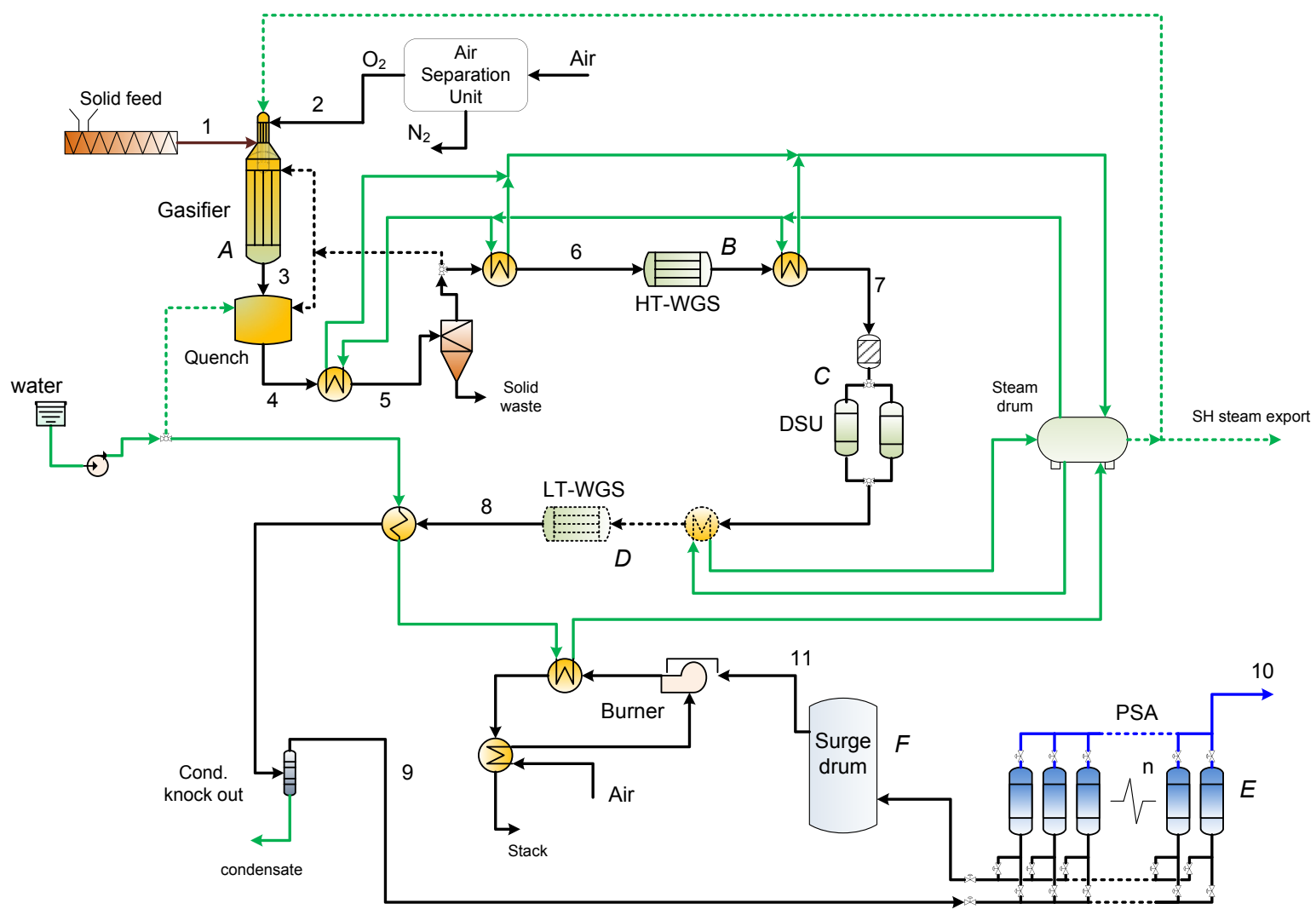

Fig. 7 - Configuration 6 - Gasification of solid fuels. 
Heat recovery is generally very important in terms of plant global efficiency; however a detailed description of heat integration with other processes (including the applications within power plants) is very case-dependent and beyond the scope of this work.

At gasifier outlet, the stream contains solid particles ("fly ash"); most of them are separated by the water quench where adopted, but in any case a solid separator (cyclones, scrubbers or electrostatic precipitators) is included before the convective heat exchangers and the catalytic reactors (WGS), whose surfaces would be otherwise damaged by the particles.

A significant difference with respect to hydrogen production from gaseous or liquid feeding is the removal of sulphur compounds. Direct removal of sulphur compounds in the gasification reactor can be carried out only in fluidized bed gasifiers by means of limestone addition within the reactor. In the other cases, a desulphurization unit (DSU) is introduced downstream the reactor, with the same working principles described for the case of steam reforming process (Section Large scale steam reforming of natural gas).

The water gas shift section converts the large amount of $\mathrm{CO}$ in the syngas to hydrogen; they can be separated in two reactors according to operating temperature, with the same characteristics already described for the WGS reactors in hydrogen production plants operating with gaseous fuels. The low temperature WGS catalysts are very sensitive to sulphur poisoning and therefore they are arranged downstream the DSU unit; according to the requirement of the final hydrogen purification section, WGS section can be arranged with only the high temperature reactor.

Table 14 shows indicative ranges for the plant operating conditions, that can vary significantly according to the feedstock and to each technology as described before.

The gasification reactor is not simulated, due to the high variability of feeding streams, operational conditions and physical processes involved; instead we assume a typical composition range of the syngas, while the subsequent treatments (quench, WGS, purification) are calculated accordingly. Assumptions for cold desulphurization, WGS and PSA section are the same as for previous configurations. Table 15 presents a comparison of the relative size of main components.

\section{Production from electricity}

Hydrogen production from electricity is based on the water electrolysis process, according to the water splitting reaction:

$\mathrm{H}_{2} \mathrm{O} \rightarrow \mathrm{H}_{2}+\frac{1}{2} \mathrm{O}_{2}$

that requires a DC electrical input. The reaction can be split in two steps (water reduction and oxidation of the intermediate ions) that take place separately on two metallic electrodes, where the two gases (hydrogen and oxygen) are generated; an electrolyte is interposed between the electrodes in order to allow the intermediate ions to flow. The nature of this electrolyte and of the ions distinguishes and classifies the different electrolysis technologies. The electrodes materials are usually studied in order to catalyse the reactions and improve the efficiency of the process.

Table 15 - Configuration 6 - Gasifier - Indicative relative size of relevant components.

\begin{tabular}{lll}
\hline Config. ref. & \multicolumn{1}{c}{ Description } & Relative size \\
\hline A & Entrained flow reactor & $++/+++$ \\
B & High-temperature WGS & $+/++$ \\
C & Desulphurization unit & + \\
D & Low-temperature WGS & $+/++$ \\
E & Pressure Swing Adsorption & +++ \\
F & Surge drum & +++ \\
G & Air separation unit & +++ \\
\hline
\end{tabular}

Table 14 - Configuration 6 - Gasifier - Operating condition.

\begin{tabular}{|c|c|c|c|c|c|c|c|c|c|c|c|c|}
\hline \multirow[t]{2}{*}{ Point } & \multirow{2}{*}{$\frac{\mathrm{P}}{\left[\mathrm{bar}_{\mathrm{a}}\right]}$} & \multirow{2}{*}{$\frac{\mathrm{T}}{\left[{ }^{\circ} \mathrm{C}\right]}$} & \multirow{2}{*}{$\frac{F}{\left[{ }^{d}\right]}$} & \multicolumn{8}{|c|}{ Composition (\% molar) } & \multirow[t]{2}{*}{ Notes } \\
\hline & & & & $\mathrm{C}_{\mathrm{x}} \mathrm{H}_{\mathrm{y}}$ & $\mathrm{H}_{2}$ & $\mathrm{CO}$ & $\mathrm{CO}_{2}$ & $\mathrm{H}_{2} \mathrm{O}$ & $\mathrm{O}_{2}$ & $\mathrm{~N}_{2}$ & $\mathrm{H}_{2} \mathrm{~S}$ & \\
\hline 1 & $23 \div 82$ & $60 \div 100$ & e & \multicolumn{9}{|c|}{ Coal + nitrogen (lock-hoppers) } \\
\hline 2 & $25 \div 85$ & $160 \div 200$ & e & $<1$ & - & - & - & - & $92 \div 95$ & $<5$ & - & Highly reactive \\
\hline 3 & $20 \div 80$ & $500 \div 1400$ & $1.1 \div 3.1$ & $<1$ & $20 \div 40$ & $40 \div 60$ & $1 \div 20$ & $2 \div 8$ & - & $<10$ & $<1$ & Contains fly-ashes \\
\hline 4 & $18 \div 78$ & $\begin{array}{l}300 \div 400^{a} \\
800 \div 900^{b}\end{array}$ & $1.5 \div 4.0$ & $<1$ & $17 \div 40$ & $35 \div 60$ & $1 \div 20$ & $2 \div 30$ & - & $<10$ & $<1$ & Contains fly-ashes \\
\hline $5^{c}$ & $17 \div 77$ & $450 \div 650$ & $1.5 \div 4.0$ & $<1$ & $17 \div 40$ & $35 \div 60$ & $1 \div 20$ & $2 \div 30$ & - & $<10$ & $<1$ & Contains fly-ashes \\
\hline 6 & $15 \div 75$ & $250 \div 450$ & $1.5 \div 4.0$ & $<1$ & $17 \div 40$ & $35 \div 60$ & $1 \div 20$ & $2 \div 30$ & - & $<10$ & $<1$ & Flammable/toxic \\
\hline 7 & $14 \div 74$ & $150 \div 350$ & $1.5 \div 4.0$ & $<1$ & $37 \div 55$ & $10 \div 40$ & $20 \div 40$ & $2 \div 20$ & - & $<10$ & $<1$ & Flammable/toxic \\
\hline 8 & $10 \div 70$ & $100 \div 200$ & $1.5 \div 4.0$ & $<1$ & $40 \div 70$ & $1 \div 10$ & $25 \div 50$ & $1 \div 5$ & - & $<10$ & $<1 \mathrm{ppm}$ & Flammable/toxic \\
\hline 9 & $9 \div 69$ & $30 \div 60$ & $1.4 \div 3.8$ & $<1$ & $42 \div 73$ & $1 \div 11$ & $26 \div 52$ & $0.1 \div 0.9$ & - & $<10$ & $<1 \mathrm{ppm}$ & Flammable/toxic \\
\hline 10 & $5 \div 65$ & $30 \div 60$ & $0.9 \div 1.2$ & $<0.1$ & Gr. 5.0 & $<0.2$ & $<0.2$ & $<0.1$ & - & $<0.2$ & - & Flammable \\
\hline 11 & $1 \div 1.5$ & $10 \div 40$ & $0.5 \div 2.9$ & $2 \div 5$ & $21 \div 50$ & $6 \div 12$ & $39 \div 60$ & $0.3 \div 3$ & - & $<0.6$ & - & Flammable/toxic \\
\hline $\begin{array}{l}\text { Bold: a } \\
\text { a Teml } \\
\text { b Tem } \\
\text { c In ca } \\
\text { d All fl } \\
\text { e Inlet } \\
\text { stoic }\end{array}$ & $\begin{array}{l}\text { sumption } \\
\text { erature in } \\
\text { erature in } \\
\text { e of total } \\
\text { ws are in } \\
\text { solid flow } \\
\text { iometric. }\end{array}$ & $\begin{array}{l}\text { from literat } \\
\text { case of com } \\
\text { case of part } \\
\text { luench, this } \\
\mathrm{Nm}^{3} / \mathrm{h} \text { relati } \\
\text { highly depe }\end{array}$ & $\begin{array}{l}\text { re data. } \\
\text { lete quenc } \\
\text { l quench. } \\
\text { oint coinc } \\
\text { e to a pro } \\
\text { ds on the }\end{array}$ & $\begin{array}{l}\text { (furth } \\
\text { es wit } \\
\text { ction } \\
\text { nature }\end{array}$ & $\begin{array}{l}\text { heat exc } \\
\text { 4. } \\
1 \mathrm{Nm} 3 / \mathrm{h} \\
\text { the fee }\end{array}$ & $\begin{array}{l}\text { f hydro } \\
\text { ng and }\end{array}$ & its $c c$ & osition; & aximum & . & low is a & $20 \div 30 \%$ of the \\
\hline
\end{tabular}


The thermodynamics of the process is improved at higher temperature, while working with water at higher pressures requires a higher electrical input but allows obtaining an already pressurized hydrogen flow, reducing or elimi-nating (for low pressure applications) the necessity of com-pressors typically very energy demanding - downstream the electrolyser. Therefore, a large research effort is presently made in order to solve the mechanical and practical issues that limit the operating temperature and pressure.

Two different technologies are currently available on the market, that differ for the nature of the intermediate ions and therefore of the electrolyte interposed between the electrodes. The first one is the alkaline electrolyser in which the electrolyte is an aqueous solution of an alkali (usually potassium or sodium); the electrolyte is liquid and circulates in the system with the feeding water. The alternative is the PEM electrolyser (Polymer Electrolyte Membrane or Proton Exchange Membrane) in which the electrodes are separated by a solid polymeric electrolytic layer. In the following both of them will be analysed in detail, in order to evidence their features and the common operational conditions.

In both the cases the system is essentially composed by a stack of cells, in which the reaction takes place, and by some auxiliary devices. A typical configuration of the whole system is shown in Fig. 8.

The main feedings are demineralized water and electricity. The main component is the stack (A) composed of a large number of cells; its size varies depending on the production required. For large scale plants, many stacks can be connected in parallel with common auxiliaries in order to reach the required production level. In fact, electrolysis system are completely modular and in principle the same scheme can be easily extended to any plant size.

The internal connection of the electrolysis cells in the stack can be in parallel (monopolar electrodes) or in series (bipolar electrodes). The first configuration makes each cell electrically independent from the next; as a consequence, the component is more reliable and the maintenance easier. In the bipolar configuration the single electrode is both the positive pole of a cell and the negative of the next; this leads to more compact stacks.

Depending on the customer requirements, the oxygen generated in the process can be directly vented in air; in this case the right section of the scheme (indicated by "O" in stream labels) is no more present.

The purification section can be present or not, according to the requirements on hydrogen purity. Without purification, a hydrogen purity of about $99.9 \%$ can be reached, thanks to the absence of contaminants in the system feeding (demineralised water). The presence of the purification section can lead to very high purity $(99.999 \%$ or grade 5.0 ) removing residual water and oxygen traces. Fig. 9 shows a typical configuration for the purification section.

After an electrical heating, the hydrogen current passes through a catalytic bed that activates the combustion of the residual traces of oxygen. The current is than cooled and the condensed water removed. In order to avoid the use of sophisticated cooling systems, the residual water is removed by means of absorption beds, whose number depends on the gas flow, that are operated cyclically in absorption/regeneration. Regeneration is carried out by means of a pressure swing cycle and a flow of recirculated pure hydrogen.

The system requires an electric power input which is proportional to the plant size (in terms of hydrogen production rate). The electrical section, that basically includes a transformer (AC/AC) and a rectifier (AC/DC) to generate the DC current consumed by the electrolysis stack, can assume a significant role in the balance of plant. Usually power electronic components are located in a separate cabinet in order to guarantee safety.

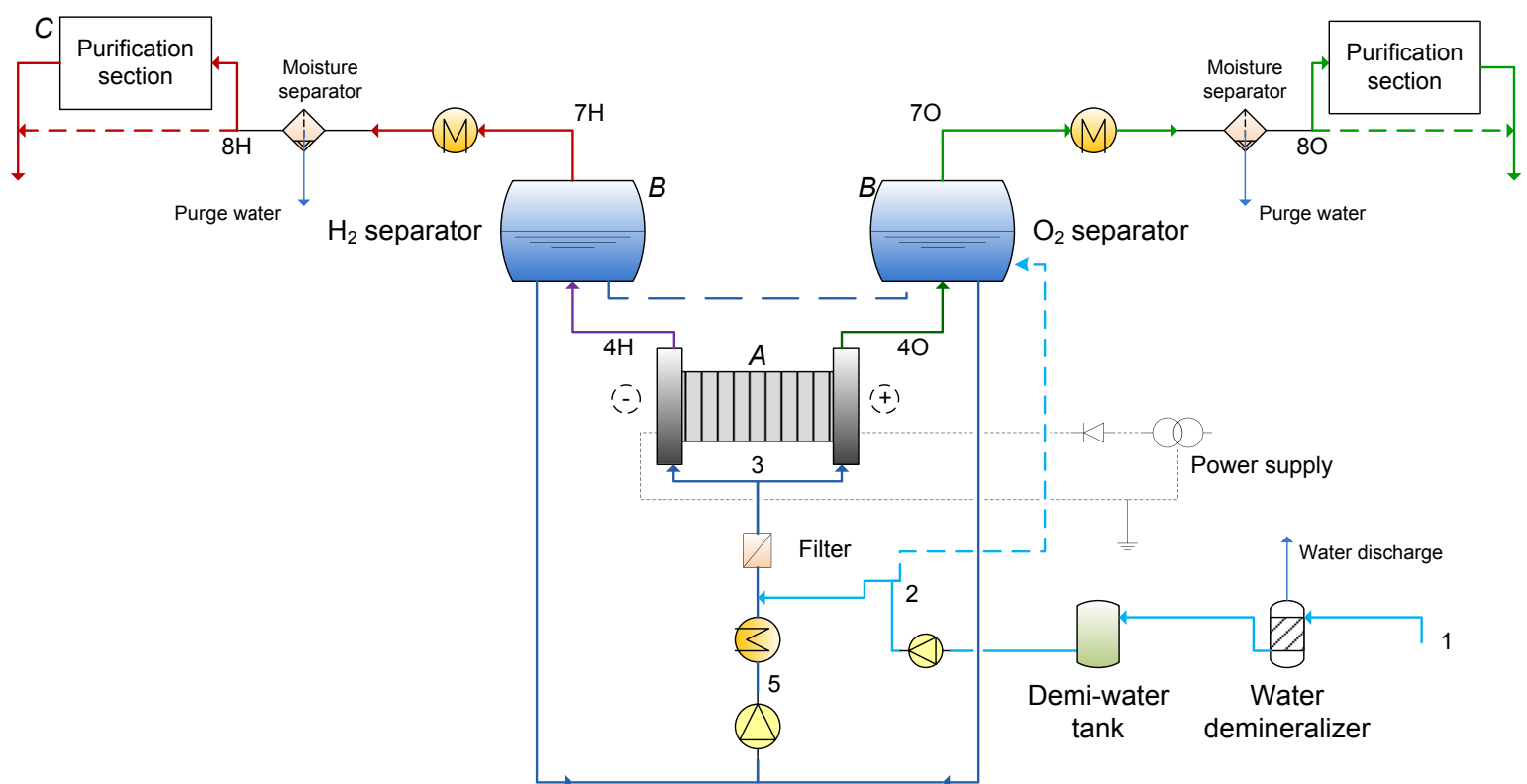

Fig. 8 - Electrolysis system configuration. 


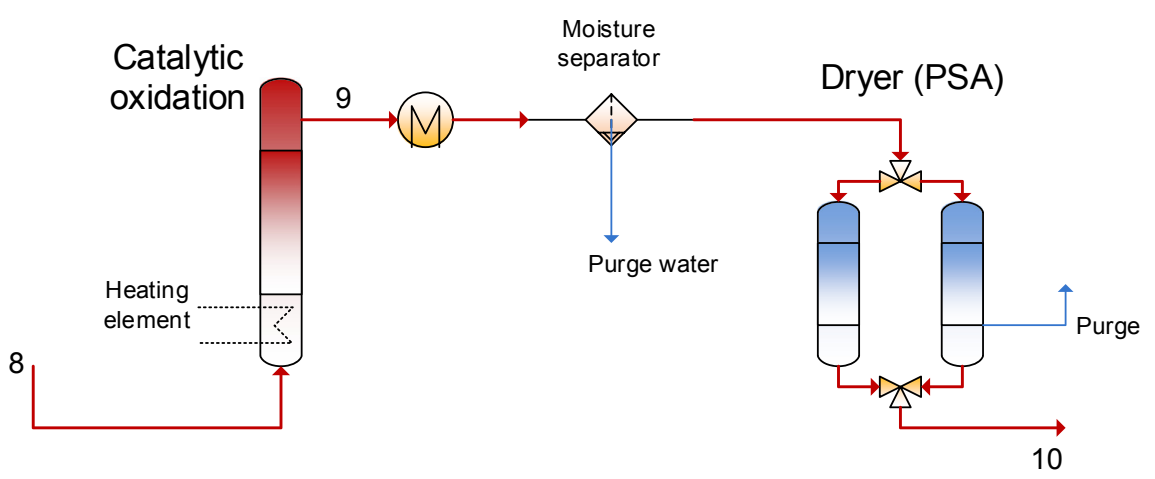

Fig. 9 - Detail of "Purification section" in electrolysis systems configuration.

\section{Alkaline electrolysis}

Alkaline electrolysers represent a very mature technology that is the current standard for large-scale electrolysis, due to the large number of installed units in operation (the first is reported to have entered service in 1902 [21]) and due to the proved performances in terms of durability, reliability and safety [21]. Thanks to the modularity of the electrolysis technology, hydrogen production plants based on alkaline electrolysers are available from low to high hydrogen outputs (e.g. $>10.000 \mathrm{Nm}^{3} / \mathrm{h}$ for large installations coupled with hydroelectric plants). Larger systems are currently operated at atmospheric pressure, while in case of medium scale systems, also pressurized units (up to 30 bar) are available on the market. The single electrolysis stack is usually rated for some hundreds of $\mathrm{Nm}^{3} / \mathrm{h}$ at atmospheric pressure, while pressurized units are currently smaller (at most $10 \div 15 \mathrm{Nm}^{3} / \mathrm{h}$ ); nevertheless, a large number of them can be put in parallel to reach higher production. Alkaline electrolysers usually operate with efficiencies in the range of $40 \div 80 \%{ }^{1}$ [22]. A list of main manufacturers and available systems can be found in Refs. [22,23]. Anode and cathode materials are typically nickel-plated steel and steel respectively, while the electrolyte is a liquid based on a highly caustic $\mathrm{KOH}$ solution in water, or more rarely a $\mathrm{NaOH}$ solution. The concentration of the alkali usually ranges between $25 \%_{\mathrm{w}}$ and $30 \%_{\mathrm{w}}$ in order to minimize the ohmic resistance of the electrolyte and to improve the performances. The charge carrier is the hydroxide ion $\left(\mathrm{OH}^{-}\right)$ exchanged between the electrodes through the electrolyte.

With reference to the previous scheme (Figs. 8 and 9), the operational conditions of an alkaline electrolyser, later referred to as Configuration 7, are listed in Table 16. Mass balances and thermophysical properties are calculated based on reaction stoichiometry.

In addition, a membrane (diaphragm) is always interposed in the gap between the electrodes, in order to avoid dangerous mixing of the gas products in this narrow space, separating the gases evolving at the electrodes. However the $\mathrm{OH}^{-}$ions must permeate through the diaphragm to reach the electrodes and keep the reaction on; therefore this component is critical both for safety and for performances. To preserve its integrity it is very important to keep a correct pressure balance

\footnotetext{
${ }^{1}$ Efficiency defined as ratio between the produced hydrogen LHV and the electrical energy input.
}

between the hydrogen and the oxygen side. The production rate is usually limited to $20 \% \div 100 \%$ of the nominal range, in order to prevent conditions that could potentially lead to the formation of flammable mixtures.

This system works at low temperatures due to the electrolyte nature (a water solution) and to materials requirements; in fact, the structure of the stack must resist at high pressure in a corrosive environment. R\&D activities are made on materials improvement, also in order to rise the operating temperature, with advantages in terms of lower electrolyte resistance and higher efficiency.

One of the main safety issues is the presence of a large amount of caustic electrolytic solution circulating in the system (as a rule of thumb, about $100 \mathrm{~L}$ in a $10 \mathrm{Nm}^{3} / \mathrm{h}$ system). In case of pressurized electrolysers a particular attention must be paid to the presence of this large inventory of pressurized liquid.

In Table 17, the sizes of the main components are compared.

Among the main components, the size of the electrical conditioning system is relevant; however, it's usually separated from the electrolysis system in a different cabinet.

The water fed to the system has to be relatively pure (below $5 \mu \mathrm{S} / \mathrm{cm}$ ) in order to preserve membrane from ions such as $\mathrm{Cl}$ or Ca which reduce its durability.

\section{PEM electrolysis}

PEM electrolyser technology is more recent than alkali electrolysis, and is originated from the R\&D developed in the 1950s for compact and reliable space applications. Nowadays, electrolysers based on this technology are commercially available, usually for small and medium scale applications, although few manufacturing companies are on the market. Specific investment costs tend to be higher than for the alkaline technology due to the limited production capacity and still not solved lifetime issues. Production rate for a single stack is currently in the order of $30 \mathrm{Nm}^{3} / \mathrm{h}$ with efficiency in the order of $40 \div 60 \%^{2}$ [21]. Some companies are working on much higher sizes (about $1 \mathrm{MW}$ ).

In this case the electrolyte is a thin (below $0.2 \mathrm{~mm}$, zero-gap configuration) polymeric membrane with a strongly acid character; this material, once properly wetted with water, can

\footnotetext{
${ }^{2}$ Efficiency defined as ratio between the produced hydrogen LHV and the electrical energy input.
} 
Table 16 - Configuration 7 - Operational condition of alkaline electrolyser.

\begin{tabular}{|c|c|c|c|c|c|c|c|c|c|}
\hline \multirow[t]{2}{*}{ Point } & \multirow{2}{*}{$\frac{\mathrm{P}}{\left[\mathrm{bar}_{\mathrm{a}}\right]}$} & \multirow{2}{*}{$\frac{\mathrm{T}}{\left[{ }^{\circ} \mathrm{C}\right]}$} & \multirow{2}{*}{$\frac{F}{[a]}$} & \multirow{2}{*}{$\frac{\mathrm{G}}{[\mathrm{kg} / \mathrm{h}]}$} & \multicolumn{4}{|c|}{ Composition (\% molar) } & \multirow[t]{2}{*}{ Notes } \\
\hline & & & & & $\mathrm{H}_{2} \mathrm{O}$ & $\mathrm{KOH}$ & $\mathrm{O}_{2}$ & $\mathrm{H}_{2}$ & \\
\hline 1 & 1 & 15 & - & $1.2 \div 2$ & 100 & - & - & - & - \\
\hline 2 & $1 \div 40$ & 15 & - & $0.8 \div 1.2$ & 100 & - & - & - & - \\
\hline 3 & $1 \div 40$ & $20 \div 50$ & - & $20 \div 40$ & Balance & $10 \div 15$ & - & - & Caustic/corrosive \\
\hline $4 \mathrm{H}$ & $1 \div 40$ & $70 \div 90$ & - & $10 \div 20$ & $78 \div 85$ & $10 \div 15$ & - & $4 \div 7$ & Caustic/corrosive \\
\hline 40 & $1 \div 40$ & $70 \div 90$ & - & $10 \div 20$ & $80 \div 88$ & $10 \div 15$ & $2 \div 4$ & - & Caustic/corrosive \\
\hline 5 & $1 \div 40$ & $70 \div 90$ & - & $20 \div 40$ & Balance & $10 \div 15$ & - & - & Caustic/corrosive \\
\hline 6 & $1 \div 40$ & $20 \div 50$ & - & $20 \div 40$ & Balance & $10 \div 15$ & - & - & Caustic/corrosive \\
\hline $7 \mathrm{H}$ & $1 \div 40$ & $70 \div 90$ & 1.0 & - & Saturation & - & Traces & Balance & Flammable \\
\hline $8 \mathrm{H}$ & $1 \div 40$ & $20 \div 40$ & 1.0 & - & Saturation & - & $<0.5$ & Gr. $2.5-3.0$ & Flammable \\
\hline $9 \mathrm{H}$ & $1 \div 40$ & $50 \div 200$ & 1.0 & - & Saturation & - & $0 \div 0.001$ & Gr. $4.5-5.0$ & Flammable \\
\hline $10 \mathrm{H}$ & $1 \div 40$ & $20 \div 40$ & 1.0 & - & $<1 \mathrm{ppm}$ & - & $0 \div 0.001$ & Gr. $4.5-5.0$ & Flammable \\
\hline 70 & $1 \div 40$ & $70 \div 90$ & 0.5 & - & Saturation & - & Balance & Traces & Highly reactive \\
\hline 80 & $1 \div 40$ & $20 \div 40$ & 0.5 & - & Saturation & - & Gr. $2.0-3.0$ & $<1$ & Highly reactive \\
\hline 90 & $1 \div 40$ & $50 \div 200$ & 0.5 & - & Saturation & - & Gr. $4.5-5.0$ & $<0.01$ & Highly reactive \\
\hline 100 & $1 \div 40$ & $20 \div 40$ & 0.5 & - & $<1 \mathrm{ppm}$ & - & Gr. $4.5-5.0$ & $<0.01$ & Highly reactive \\
\hline
\end{tabular}

Table 17 - Configuration 7 - Relative size of components (alkaline electrolyser).

\begin{tabular}{lll}
\hline Config. ref. & \multicolumn{1}{c}{ Description } & Relative size \\
\hline A & Electrolytic cells stack & $++/+++$ \\
B & Separation tanks & $+/++$ \\
C & Purification section & + \\
\hline
\end{tabular}

transport protons $\left(\mathrm{H}^{+}\right)$through a ionic exchange mechanism. As for PEM fuel cells, the most commonly used membrane is the Nafion ${ }^{\mathrm{TM}}$.

The electrodes are assembled on two layers: a support on which are built water feeding and gas removing channels, and a thin porous catalytic layer (platinum or iridium based). For this technology, the bipolar configuration is almost always adopted.
Table 19 - Configuration 8 - Relative size of components (PEM electrolyser).

\begin{tabular}{llc}
\hline Config. ref. & \multicolumn{1}{c}{ Description } & Relative size \\
\hline A & Electrolytic cells stack & ++ \\
B & Separation tanks & $+/++$ \\
C & Purification section & + \\
\hline
\end{tabular}

With reference to the previous scheme (Figs. 8 and 9), Table 18 lists common operational conditions of a PEM electrolyser system, later referred to as Configuration 8.

Thanks to the internal structure of the cell (zero-gap) and to the small sizes allowed by operating at higher current densities with respect to the alkaline electrolysers, PEM electrolysers are very compact and could reach higher pressures (currently up to 85 bar); nevertheless commercial models are

Table 18 - Configuration 8 - Operational condition of PEM electrolyser.

\begin{tabular}{|c|c|c|c|c|c|c|c|c|}
\hline \multirow[t]{2}{*}{ Point } & \multirow{2}{*}{$\frac{\mathrm{P}}{\left[\mathrm{bar}_{\mathrm{a}}\right]}$} & \multirow{2}{*}{$\frac{\mathrm{T}}{\left[{ }^{\circ} \mathrm{C}\right]}$} & \multirow{2}{*}{$\frac{\mathrm{F}}{[\mathrm{a}]}$} & \multirow{2}{*}{$\frac{\mathrm{G}}{[\mathrm{kg} / \mathrm{h}]}$} & \multicolumn{3}{|c|}{ Composition (\% molar) } & \multirow[t]{2}{*}{ Notes } \\
\hline & & & & & $\mathrm{H}_{2} \mathrm{O}$ & $\mathrm{O}_{2}$ & $\mathrm{H}_{2}$ & \\
\hline 1 & 1 & 15 & - & $1.2 \div 2$ & 100 & - & - & - \\
\hline 2 & $1 \div 85$ & 15 & - & $0.8 \div 1$ & 100 & - & - & - \\
\hline 3 & $1 \div 85$ & $20 \div 50$ & - & $1.5 \div 10$ & 100 & - & - & - \\
\hline $4 \mathrm{H}$ & $1 \div 85$ & $50 \div 80$ & - & $0.1 \div 5$ & $0.1 \div 85$ & Traces & $4 \div 99.9$ & Flammable \\
\hline 40 & $1 \div 85$ & $50 \div 80$ & - & $1 \div 5$ & $80 \div 88$ & $2 \div 4$ & - & - \\
\hline 5 & $1 \div 85$ & $50 \div 80$ & - & $1.5 \div 10$ & 100 & - & - & - \\
\hline 6 & $1 \div 85$ & $20 \div 50$ & - & $1.5 \div 10$ & 100 & - & - & - \\
\hline $7 \mathrm{H}$ & $1 \div 85$ & $50 \div 80$ & 1.0 & - & Saturation or traces & Traces & Balance & Flammable \\
\hline $8 \mathrm{H}$ & $1 \div 85$ & $20 \div 40$ & 1.0 & - & Saturation or traces & Traces & Gr. 3.0-5.0 & Flammable \\
\hline $9 \mathrm{H}$ & $1 \div 85$ & $50 \div 200$ & 1.0 & - & Saturation or traces & $0 \div 0.001$ & Gr. $4.5-5.0$ & Flammable \\
\hline $10 \mathrm{H}$ & $1 \div 85$ & $20 \div 40$ & 1.0 & - & $<1 \mathrm{ppm}$ & $0 \div 0.001$ & Gr. $4.5-5.0$ & Flammable \\
\hline 70 & $1 \div 85$ & $50 \div 80$ & 0.5 & - & Saturation & balance & - & Highly reactive \\
\hline 80 & $1 \div 85$ & $20 \div 40$ & 0.5 & - & Saturation & Gr. 2.0-3.0 & $<1$ & Highly reactive \\
\hline 90 & $1 \div 85$ & $50 \div 200$ & 0.5 & - & Saturation & Gr. $4.0-4.5$ & $<0.01$ & Highly reactive \\
\hline 100 & $1 \div 85$ & $20 \div 40$ & 0.5 & - & $<1 \mathrm{ppm}$ & Gr. $4.0-4.5$ & $<0.01$ & Highly reactive \\
\hline
\end{tabular}




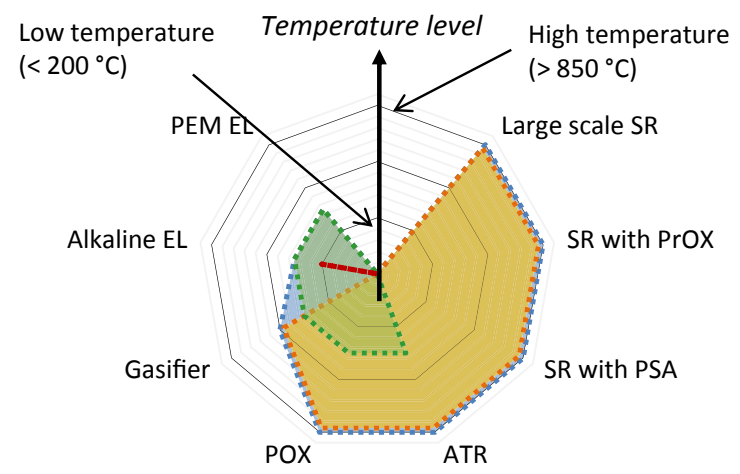

(a) WFlammable gases :Highly Reactive gases

\begin{abstract}
WToxic gases
\end{abstract}
:Caustic liquids

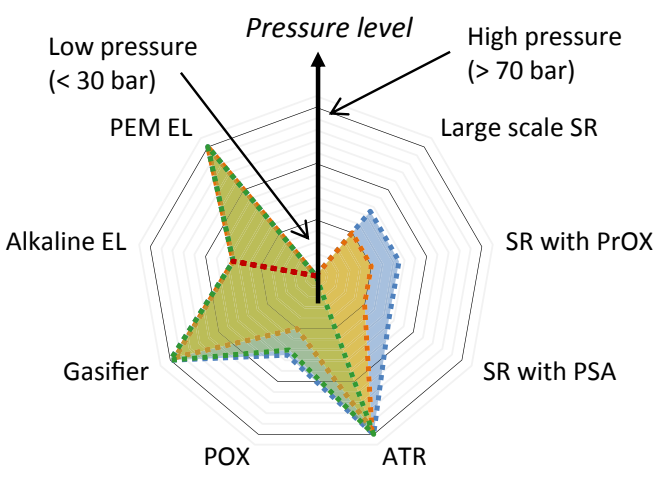

(b)
iFlammable gases
\#Toxic gases
"Highly Reactive gases

Fig. 10 - Qualitative comparison of technologies from the point of view of presence of dangerous conditions due to (a) high temperature and/or (b) high pressure.

designed for lower pressures (below about 30 bar) because of a lack of large-scale plant operational experience. The structural properties allow a differential pressure between the hydrogen and the oxygen side, although few models are designed for both hydrogen and oxygen recovery. On the other hand, the presence of the polymeric membrane limits the temperatures at about $80^{\circ} \mathrm{C}$.

Due to the reduced permeability of the membrane to gases, this technology can be operated in the whole regulation range and can tolerate a current $20 \%$ over the nominal for short time periods. In fact, the risk of formation of flammable mixtures in the cell is low. Moreover, the system shows a lower inertia than the alkaline one; fast changes in power regulation are therefore allowed. In Table 19, the sizes of the main components are compared.

With respect to the alkaline electrolyser, the stack is more compact; however, the size of power electronics devices is the same, while a higher purity of the feeding water is required (about $1 \mu \mathrm{S} / \mathrm{cm}$ ).

\section{Technologies comparison and conclusions}

For each selected type of plant, a corresponding plant layout was developed with a common framework, evaluating with a specific table the related stream operating conditions (pressure, temperatures, mass flow rates, chemical composition and presence of flammable components). An additional analysis compares the most important plant components by the point of view of relative size, evaluated on a qualitative basis aiming to evidence the presence of bulky equipment, especially when processing hazardous streams.

General results are summarized in Fig. 10 as a qualitative comparison of the investigated technologies, considering dangerous conditions at (a) high temperature and (b) high pressure. The presence of flammable and toxic mixtures at high temperature is common to all the natural gas fed technologies, while coal gasification and electrolysis handle this kind of gases at lower temperatures. From the point of view of pressure, ATR and gasifier exhibit flammable and toxic gases at high pressures, while common pressure of SR is lower. Highly reactive gas (mainly pure oxygen) is present in ATR, POX, gasifier and electrolysis usually at low temperature and high-to-mid pressures. Caustic solutions are typical of alkaline electrolysis.

Moreover, it has to be reminded that large scale technologies are typically industrial and therefore located in a monitored environment with proper safety procedures. On the other hand, electrolysis and small scale ATR/SR are technologies suitable for local production of hydrogen (fuelling stations, domestic cogeneration); consequently, they will require a higher safety standard that can anyway take into account the reduced dimension of the system. Reforming units manage high flows of flammable and toxic species (i.e. hydrogen, carbon monoxide) in large reactors; these quantities can be even larger for gasification units. Large purification units have to treat these flows, aided by large surge tanks containing the released impurities. On the other hand, electrolysis system are usually modular with smaller auxiliary devices and accumulation of dangerous mixtures. Large alkaline electrolysis systems remain the exception with large amount of circulating caustic solution. Specific features of the plants in terms of involved chemicals (e.g. catalysts) were also listed during the discussion. This work can support a subsequent safety evaluation, since an analysis of the recurrence of streams featuring high pressure/high temperature/high content of combustible, chemically reactive or toxic species, as well as the presence of large size reactors with hazardous contents, could address in evaluating how critical is a certain plant by the point of view of safety.

\section{Acknowledgements}

This work has been based on the results of the European project H2TRUST (Grant Agreement no: 325357), ref. Task 2.2, cofounded by the FCH-JU.

\section{Nomenclature}

\author{
Acronyms \\ ATR Auto-Thermal Reforming \\ CO-PrOX CO Preferential Oxidation
}




$\begin{array}{ll}\text { CPO } & \text { Catalytic Partial Oxidation } \\ \text { DSU } & \text { De-Sulphurization Unit } \\ \text { FTR } & \text { Fired tubular reformer } \\ \text { NG } & \text { Natural gas } \\ \text { PEM } & \text { Polymeric Electrolyte Membrane (Proton Exchange } \\ & \text { Membrane) } \\ \text { POX } & \text { Partial OXidation } \\ \text { SR } & \text { Steam Reforming } \\ \text { WGS } & \text { Water Gas Shift }\end{array}$

\section{R E F E R E N C E S}

[1] Ball M, Wietschel M. The future of hydrogen - opportunities and challenges. Int J Hydrogen Energy 2009;34(2):615-27. http://dx.doi.org/10.1016/j.ijhydene.2008.11.014.

[2] Edwards PP, Kuznetsov VL, David WIF, Brandon NP. Hydrogen and fuel cells: towards a sustainable energy future. Energy Policy 2008;36(12):4356-62. http://dx.doi.org/10.1016/ j.enpol.2008.09.036.

[3] Ball M, Weeda M. The hydrogen economy - vision or reality? Int J Hydrogen Energy 2015;40(25):7903-19. http://dx.doi.org/ 10.1016/j.ijhydene.2015.04.032. 6 July 2015.

[4] Gallucci F, Fernandez E, Corengia P, van Sint Annaland M. Recent advances on membranes and membrane reactors for hydrogen production. Chem Eng Sci 2013. http://dx.doi.org/ 10.1016/j.ces.2013.01.008.

[5] Dalebrook AF, Gan W, Grasemann M, Moret S, Laurenczy G. Hydrogen storage: beyond conventional methods. Chem Commun 2013;49(78):8735-51. http://dx.doi.org/10.1039/ c3cc43836h

[6] Gazzani M, Chiesa P, Martelli E, Sigali S, Brunetti I. Using hydrogen as gas turbine fuel: premixed vs. diffusive flame combustors. J Eng Gas Turbines Power 2014;136(5). http:// dx.doi.org/10.1115/1.4026085.

[7] Bennoua S, Le Duigou A, Quéméré M-M, Dautremont S. Role of hydrogen in resolving electricity grid issues. Int J Hydrogen Energy 2015;40(23):7231-45. http://dx.doi.org/10.1016/ j.ijhydene.2015.03.137.
[8] IEA (international Energy Agency). Technology roadmap hydrogen and fuel cells. OECD/IEA Paris; 2015.

[9] Molkov V. Hydrogen safety engineering: the state-of-the-art and future progress. Earth Planet Sci 2012;4:97-129. http:// dx.doi.org/10.1016/B978-0-08-087872-0.00418-2.

[10] H2TRUST, www.h2trust.eu, 2015.

[11] AA.VV., "Vol 2-Refining and petrochemicals," in ENI's Encyclopaedia of Hydrocarbons, Italian Encyclopaedia Institution, Ed. Rome, 2005.

[12] Gupta RB. Hydrogen fuel: production, transport and storage. CRC Press; 2008.

[13] Léon A. Hydrogen technology. Springer; 2008. p. 687.

[14] Kohl AL, Nielsen RB. Gas purification. 5th ed. Houston: Texas; 1997.

[15] Aspen Plus, www.aspentech.com, 2015.

[16] Holladay JD, Hu J, King DL, Wang Y. An overview of hydrogen production technologies. Catal Today Jan. 2009;139(4):244-60. http://dx.doi.org/10.1016/j.cattod.2008.08.039.

[17] Curtin S, Gangi J. Fuel cell technologies market report 2014. Washington DC, USA: DOE Report; Oct. 2015.

[18] Transparency Market Research. Hydrogen generator market - global industry analysis, size, share, growth trends, and forecast 2016-2024. March 2016. EP 2781.

[19] Christensen TS. Adiabatic prereforming of hydrocarbons an important step in syngas production. Appl Catal A Gen 1996;138:285-309. http://dx.doi.org/10.1016/0926-860X(95) 00302-9.

[20] Simpson AP, Lutz AE. Energy analysis of hydrogen production via steam methane reforming. Int J Hydrogen Energy 2007;32(18):4811-20. http://dx.doi.org/10.1016/ j.ijhydene.2007.08.025.

[21] Kreuter W, Hofmann H. Electrolysis: the important energy transformer in a world of sustainable energy. Int J Hydrogen Energy 1998;23(8):661-6. http://dx.doi.org/10.1016/ S0360-3199(97)00109-2.

[22] Ursua A, Gandia LM, Sanchis P. Hydrogen production from water electrolysis: current status and future trends. Proc IEEE 2012;100(2):410-26.

[23] Ivy J. Summary of electrolytic hydrogen production: milestone completion report, NREL/MP-560-36734. 2004. 